\title{
Mass Movement-Induced Tsunami Hazard on Perialpine Lake Lucerne (Switzerland): Scenarios and Numerical Experiments
}

\author{
Michael Hilbe $^{1,2}$ and Flavio S. Anselmetti ${ }^{2}$
}

\begin{abstract}
Previous studies of the sediments of Lake Lucerne have shown that massive subaqueous mass movements affecting unconsolidated sediments on lateral slopes are a common process in this lake, and, in view of historical reports describing damaging waves on the lake, it was suggested that tsunamis generated by mass movements represent a considerable natural hazard on the lakeshores. Newly performed numerical simulations combining two-dimensional, depth-averaged models for mass-movement propagation and for tsunami generation, propagation and inundation reproduce a number of reported tsunami effects. Four analysed mass-movement scenarios-three based on documented slope failures involving volumes of 5.5 to $20.8 \times 10^{6} \mathrm{~m}^{3}$ - show peak wave heights of several metres and maximum runup of 6 to $>10 \mathrm{~m}$ in the directly affected basins, while effects in neighbouring basins are less drastic. The tsunamis cause large-scale inundation over distances of several hundred metres on flat alluvial plains close to the mass-movement source areas. Basins at the ends of the lake experience regular water-level oscillations with characteristic periods of several minutes. The vulnerability of potentially affected areas has increased dramatically since the times of the damaging historical events, recommending a thorough evaluation of the hazard.
\end{abstract}

Key words: Natural hazards, subaqueous mass movements, mobility analysis, tsunami modelling, runup analysis.

\section{Introduction}

Tsunamis generated by submarine mass movements are receiving considerable attention as a natural hazard endangering coastal communities (e.g., BARdet et al. 2003; SATAKe 2012). Their effects are often spatially less extensive than those of

1 Department of Surface Waters, Eawag, Swiss Federal Institute of Aquatic Science and Technology, Überlandstrasse 133, 8600 Dübendorf, Switzerland. E-mail: michael.hilbe@geo.unibe.ch

2 Institute of Geological Sciences and Oeschger Centre for Climate Change Research, University of Berne, Baltzerstrasse $1+3,3012$ Berne, Switzerland. disastrous transoceanic tsunamis generated by coseismic slip of large earthquakes (e.g., Tiтоv et al. 2005; FusII et al. 2011), although large-scale collapses of continental margins and oceanic islands in prehistoric times have caused effects of similar magnitude (WARD 2001; BoNDEVIK et al. 2005; GEIST et al. 2009). Nevertheless, mass movements of limited size may also have serious consequences in a local context in their vicinity. Among the closely investigated recent examples of such tsunamis are the well-known 1998 Papua New Guinea tsunami (SyNOLAKIS et al. 2002), which showed maximum local runup of $15 \mathrm{~m}$, caused the death of more than 2000 people and was likely generated by an earthquaketriggered mass movement; as well as the smaller events of Skagway, Alaska, in 1994 (Kulikov et al. 1996; Rabinovich et al. 1999) and Nice Airport, France, in 1979 (Assier-RZADKIEWICZ et al. 2000). Triggers for the mass movements are often earthquakes that may be infrequent and that do not produce significant tsunamis through coseismic slip (TEN BRINK et al. 2009). Next to earthquakes, a number of other causes and triggers leading to the sudden failure of submerged slopes have been documented, including human influence in the form of construction works, or natural processes such as rapid water-level fluctuations (e.g., tides), which are among the suspected triggers in the latter two examples. For coastlines exposed to limited seismic activity, e.g., along passive continental margins, submarine landslides are considered the main source of tsunami hazard, and efforts are being made in order to quantify this hazard, taking into account geotechnical data on sediment types, recurrence rates of earthquakes triggering mass movements, and numerical tsunami models (e.g., WATTs 2004; GRILLI et al. 2009). 
The processes of mass movement-generated tsunamis are not restricted to the marine environment. They also occur in different lacustrine settings, e.g., in lakes within fault-bounded basins, which can show very large mass-movement volumes in relation to the lake basin (e.g., Moore et al. 2006), or in fjord-type lakes, which, like marine fjords, often feature a variety of mass-movement processes. Studies in numerous perialpine lakes in Central Europe-the glacially carved, often deep and elongated, fjord-type lake basins around the Alps and in main Alpine valleys (FINCKH et al. 1984) — have revealed ample geological evidence for large-scale subaqueous mass movements, some of which were reportedly accompanied by extraordinary water waves (e.g., SCHNELlMANN et al. 2002; KREMER et al. 2012). While different mass movements have been attributed to various causes and triggers, such as earthquakes, rockslide impacts or apparently spontaneous failures, the larger ones are generally expected to represent a considerable tsunami hazard for these lakes. However, the long recurrence times of such events, the sparseness of historical documents describing them, and also the reduced vulnerability of the rural societies in ancient times, all complicate an assessment of the actual effects of these tsunamis and the associated hazard for the present-day situation. Modern examples of mass movement-generated tsunamis in these lakes are rare, difficult to track and generally small (cf. GiRARDCLOS et al. 2007). They typically receive less attention than the more frequent and betterestablished impulse waves generated by subaerial rockslides or rockfalls entering the lakes (HUBER 1982; Fritz et al. 2004), The two processes may also be connected if the impact of a rockslide triggers a secondary subaqueous mass movement (WARD and DAY 2010; KREMER et al. 2012).

The absence of direct measurements advocates numerical modelling as an alternative for the assessment of a potential tsunami hazard. Using available geological, geophysical and historical information from Lake Lucerne, a perialpine lake with a rich and well-documented mass-movement record including historical as well as prehistoric events, this study sets up scenarios for tsunamigenic subaqueous mass movements, based on reconstructed past events and a hypothetical future event. It attempts to reproduce reported tsunami-related observations and assess the consequences of the mass movements by numerically simulating wave generation, propagation and inundation with established and publicly available models, providing information for eventual hazard assessments. The considerations are also relevant for other perialpine lakes that show extensive subaqueous mass movements and that face a similar hazard.

\section{Lake Lucerne: Setting and Past Subaqueous Mass Movements}

Lake Lucerne, which is situated in Central Switzerland on the northern margin of the Alps and involves a surface area of $113.6 \mathrm{~km}^{2}$ at an elevation of $433.6 \mathrm{~m}$ a.s.l. (BAFU 2009), includes seven main basins with water depths up to $214 \mathrm{~m}$ (Fig. 1). The southern and eastern parts of the lake are located within the Alpine nappes, while the northern basins are surrounded by rocks of the Subalpine Molasse and the Plateau Molasse, which represent imbricated and weakly deformed units of the Alpine foreland basin sediments, respectively. These main units are separated by two major thrusts, the "North Alpine Front" at the base of the Alpine nappes, and the "Subalpine Front", separating the Subalpine Molasse above from the Plateau Molasse below (Fig. 1; STRASSER et al. 2013).

Considerable parts of the lakeshore are densely inhabited, the largest community being the city of Lucerne with an overall population of $\sim 77,000$ (BFS 2013). Many slopes above the lakeshores are relatively steep, limiting the area exposed to tsunami hazard. However, apart from the fact that buildings often occupy the immediate lakeshore, there are flat areas with concentrated infrastructure and extensive residential and industrial areas in the main valleys, where ground elevation is only a few metres above normal lake level (Fig. 1).

A series of studies on the sedimentary infill of the lake and the lake-floor morphology (SIEGENTHALer et al. 1987; Siegenthaler and Sturm 1991; SCHNELlmann et al. 2002, 2006; STRASSER et al. 2007; Hilbe et al. 2011; Hilbe and Anselmetti, in press) describe signatures of subaqueous mass 


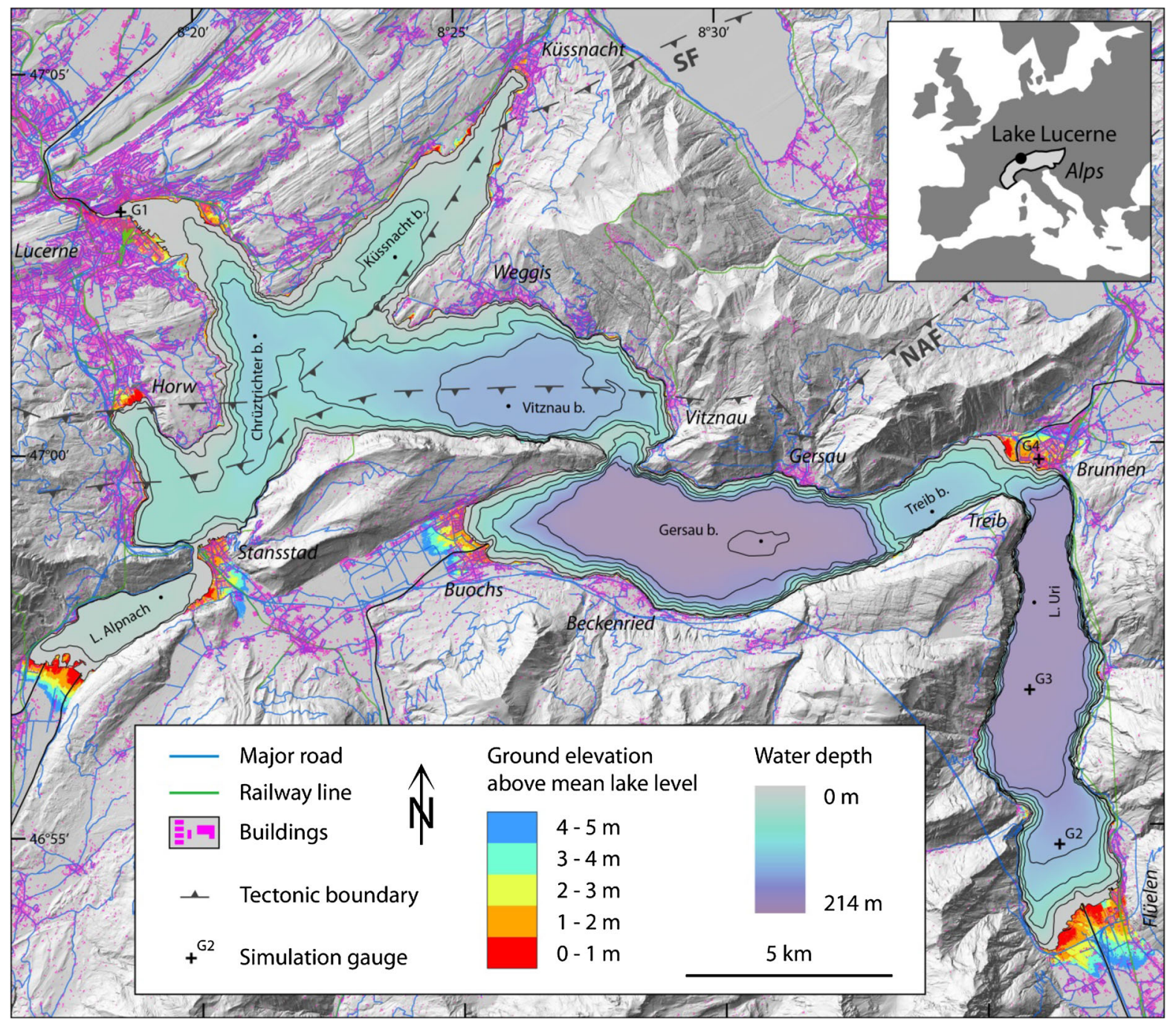

Figure 1

Lake Lucerne and surrounding areas, with buildings and main traffic infrastructure, names of villages and names of seven main lake basins. The small map in the upper right corner shows the location of the lake on the northern margin of the Alps in Central Europe. Main tributaries and the outflow in Lucerne are marked with solid black lines; contour lines within the lake have an interval of $40 \mathrm{~m}$; dots indicate the deepest points of the basins. Major tectonic boundaries are indicated (NAF North Alpine Fault, SF Subalpine Fault). Shaded relief of surroundings and mapping of ground elevation above mean lake level were generated using swisstopo swissALTI3D digital terrain model, contour lines within the lake are from the swisstopo DHM25 elevation model, traffic infrastructure and buildings are from the swisstopo swissTLM3D landscape model. All geodata by swisstopo were used with permission JA100119

movements in several basins of Lake Lucerne. Typical deposits are bodies of disturbed sediment with thicknesses of up to several metres that have been transported as deforming but coherent masses from the source areas on the submerged lateral or delta slopes ("mass-flow deposits"). They are usually overlain by homogeneous mud with a graded base ("megaturbidite"), which has been interpreted as deposits from a suspension cloud kept in motion by strong oscillations of the entire water column (SiegENTHALER et al. 1987). The more recent mass movements also show sharp escarpments as morphological traces in the source areas, which allow an assessment of the extents of the failed sediments (Hilbe et al. 2011; Hilbe and Anselmetti, in press). 


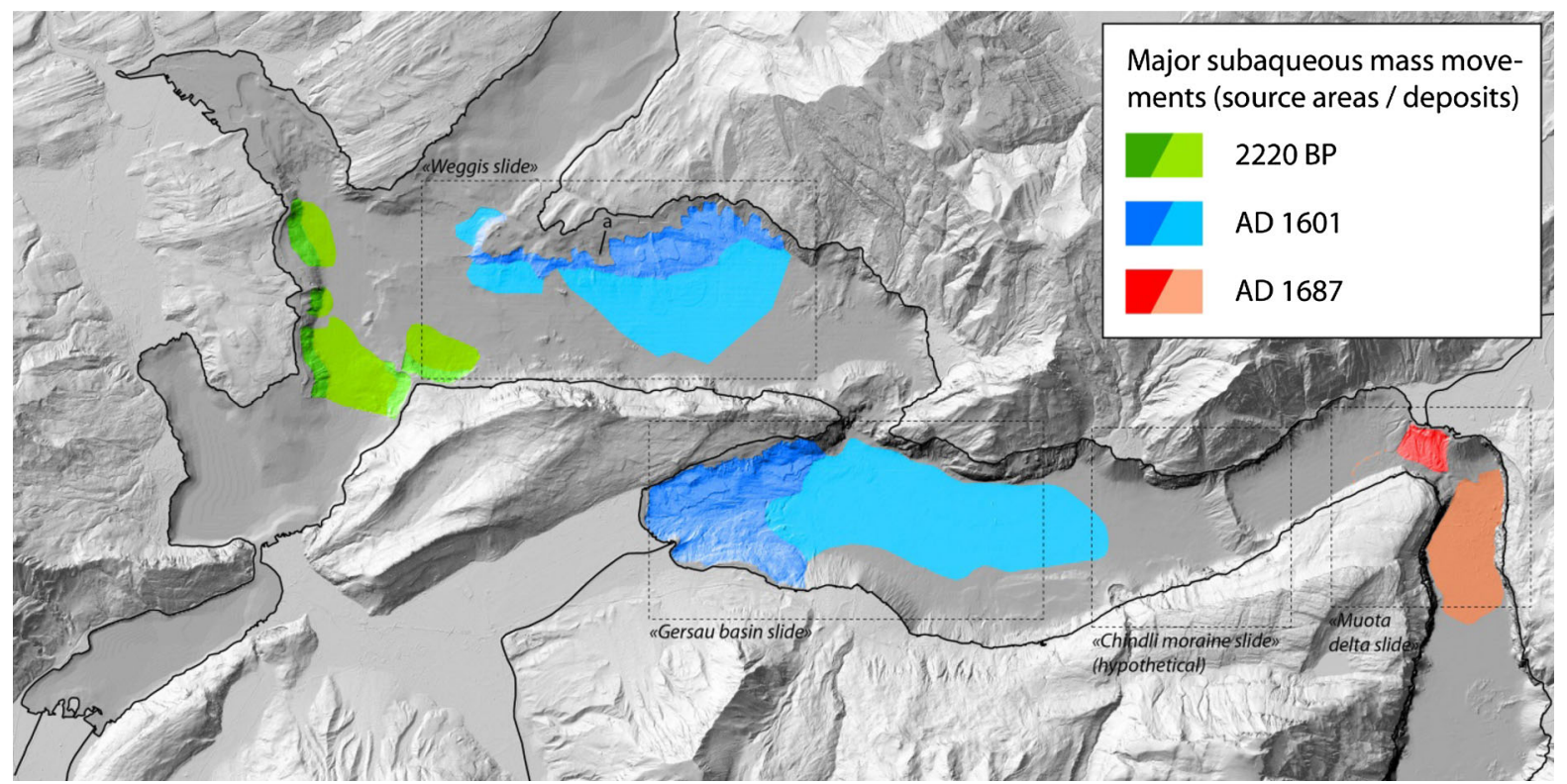

Figure 2

Lake-floor morphology and topography (shaded relief, note that scaling is different for subaerial and submerged parts), with extents of largest individual mass movements for three events: $2220 \mathrm{yr}$. BP (green), AD 1601 (blue) and AD 1687 (red). The events of $2220 \mathrm{yr}$. BP and AD 1601 additionally include numerous smaller mass movements not shown on the figure. Extents of deposits and source/transit areas are taken from Schnellmann et al. (2006), Hilbe et al. (2011) and Hilbe and Anselmetti (in press). Extents for mass-movement scenarios in Figs. 3 and 4 are indicated by dashed lines. Label 'a' marks an individual sediment package identified as potentially unstable by STRASSER et al. (2011); see "Discussion"

The reconstructions show that two major events with multiple and particularly voluminous mass movements occurring coevally in different parts of the lake, dated to $2220 \mathrm{yr}$ BP and AD 1601, as well as one with a single voluminous mass movement dated to AD 1687 (Fig. 2), have taken place in the last 3,000 years. The events of 1601 and 1687 are covered by sparse eyewitness reports of anomalous water waves, documenting runup and inundated areas. These latter events provide the basis for the scenarios for the numerical experiments. The mass movements of AD 1601 are related to an $M_{\mathrm{W}} \sim 5.9$ earthquake with an epicentre $\sim 10 \mathrm{~km}$ south of the lake (Schnellmann et al. 2002; FäH et al. 2011), which triggered ubiquitous slope failures on the submerged, gently inclined lateral slopes, affecting a hemipelagic lacustrine sediment drape of these slopes with a thickness of several metres. Two extensive failures occurred on the northern slope of the Vitznau basin ("Weggis slide") and in the western part of the Gersau basin ("Gersau basin slide"), respectively (Fig. 2; Schnellmann et al. 2006; Strasser et al.
2007; Hilbe et al. 2011; Hilbe and Anselmetti, in press).

The prehistoric event $2220 \mathrm{yr}$. BP, for which an earthquake with an estimated magnitude of 6.2-6.7 is proposed as a trigger, in analogy to the AD 1601 event (SChNEllmann et al. 2002; STRASSER et al. 2006, 2013), includes two major mass movements with still prominent morphological signatures and voluminous deposits in the western part of the Vitznau basin and in the Chrüztrichter basin (Fig. 2). The third event of AD 1687 has a different character, and involves only a single mass movement affecting coarse-grained deposits on the active delta slope of the Muota delta ("Muota delta slide" in Fig. 2). Unlike the other cases, it represents an aseismically triggered, apparently spontaneous partial collapse of a river delta due to a thus-far undocumented mechanism (SIEGENTHALER and Sturm 1991; Hilbe and Anselmetti, in press). Although the exact geometry of the failed sediments on the slope is not known, it likely involved a rather thick $(>10 \mathrm{~m})$ sediment package reaching very shallow water depths. 


\section{Numerical Models}

The assessment of the tsunami hazard posed by subaqueous mass movements includes aspects of wave generation, propagation and inundation, as well as aspects of mass-movement distribution and frequency. For Lake Lucerne, the distribution and the areas prone to failure are known from previous studies, and geotechnical aspects of failures on lateral slopes are reasonably well understood (STRASSER et al. 2007, 2011; Stegmann et al. 2007). So far, a systematic estimation of the consequences of tsunamis generated by expectable mass movements is largely missing, even though the effects of past tsunamis have been described based on historical documents (Siegenthaler et al. 1987; Hilbe and Anselmetti, in press) and one numerical study ( $\mathrm{SCH}-$ NELLMANN et al. 2002).

Numerical experiments for tsunami generation, propagation and inundation, intended to bridge this knowledge gap, were performed using a combination of two models, which simulate (1) the kinematics of the subaqueous mass movement propagating on the lake floor, and (2) the tsunami waves propagating on the lake and inundating land areas. The mass movement is simulated as a single-phase fluid propagating on the lake-floor topography, with a given, nonNewtonian rheology. The resulting time-dependent topography of the lake floor, including the moving mass, is then used as an input parameter for the generation and propagation of a tsunami wave, starting from the lake at rest ("one-way coupling"; JiANG and LeBLOND 1992). Calculations for both simulations are performed using depth-averaged variables on a Cartesian grid in two dimensions. Similar approaches have been taken in a number of previous studies (e.g., Assier-RzAdKIEwicz et al. 2000), which allowed reconstruction of the scale of tsunamis generated by submarine slides to a satisfactory level, despite the implied simplifications.

Both models use publicly available, open computer code, which has been validated against other models, real world cases or laboratory experiments. While no ready-to-use solution for the modelling of mass movement-induced tsunamis is available to the general public thus far, open codes for the individual tasks-modelling of mass-movement kinematics, as well as tsunami propagation and inundation-are becoming increasingly common. They can be readily combined and provide a simple solution for a rough assessment of the consequences.

\subsection{Simulation of Subaqueous Mass Movements}

The subaqueous mass movements are modelled using the code "MassMov2D" (version 0.91; BEGUERÍA et al. 2009) for the "PCRaster" scripting language (Wesseling et al. 1996). "MassMov2D" has been developed for the simulation of subaerial debris flows propagating over arbitrary topography as a single-phase fluid or plastic, using different rheologies. For subaqueous mass movements, "virtual" rheology parameters are determined by back-analysis of a known event. This approach is often taken for runout analyses of submarine mass movements (e.g., ImRAn et al. 2001; Locat et al. 2009; Mazzanti and Bozzano 2009). The model uses a finite difference scheme to solve depth-averaged formulations of mass and momentum balance equations (BEguería et al. 2009). One of the implemented rheologies is Bingham plastic, which is most commonly used for the modelling of fine-grained submarine mass movements (e.g., IMRAN et al. 2001; MARR et al. 2002), and therefore is also applied in the present study.

The rheology parameters are determined by backanalysis of a given mass movement from observations (topography data, position of initial volume of mass movement, runout distance, distribution of deposits), by repeatedly running simulations with varied parameters, approaching possible similarity of the simulated deposits with the geological data. Reaching the overall runout of the deposits is not always possible in the performed simulations (see below). The matching is therefore done by visually comparing the overall geometries and the positions of the depocentres of the simulated and the actual deposits. The initial volume for the mass movement on the slope is reconstructed using morphological information from bathymetry data and volumes of the deposits as constraints. However, the deposits cannot be used directly as indicators of initial landslide volume, since the bodies mapped with seismic data often include large amounts of reworked sediments, 

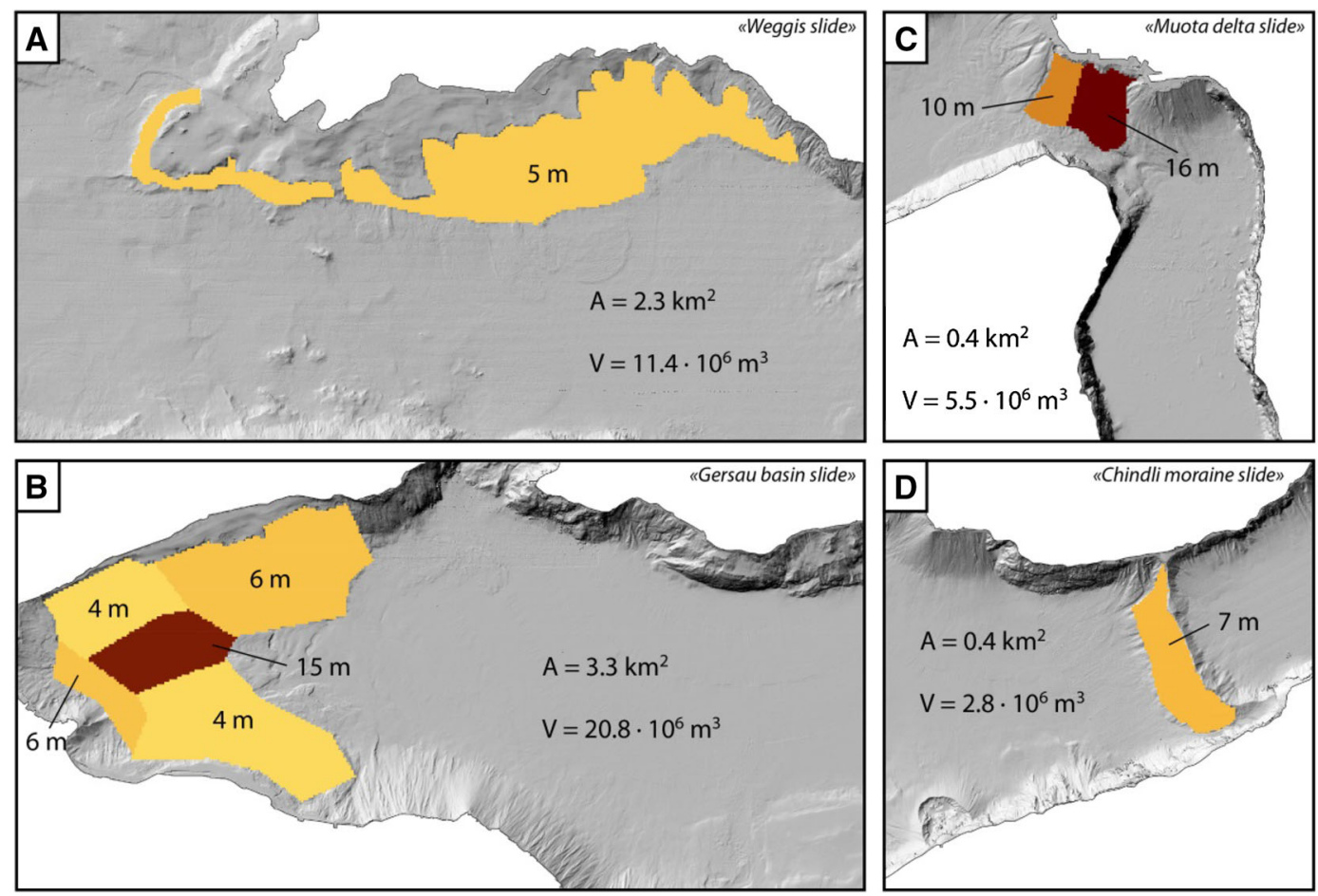

Initial thickness

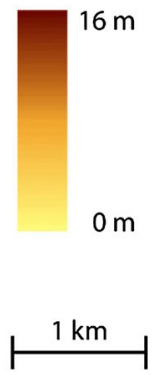

Figure 3

Initial failure volumes used for the four mass-movement scenarios, with thicknesses, covered areas and total volumes. These generalized geometries have been interpreted mainly from morphological data and deposit volumes. See Fig. 2 for locations of mass movements

which do not originate from the slopes and likely do not significantly contribute to tsunami generation (Hilbe and Anselmetti, in press). Reconstructed initial volumes are detailed in the scenarios given below and shown in Fig. 3. The onset of the mass movements in the simulations is generally assumed to occur at once, due to the lack of any geological indications of retrogressive behaviour of the failures.

\subsection{Tsunami Propagation and Inundation Modelling}

Tsunami propagation and inundation are modelled using "GeoClaw" (version 4.6.3), an open-source code simulating flow or wave propagation that has been used, for instance, for tsunami or flood calculations (BERger et al. 2011, LeVEQue et al. 2011). "GeoClaw" uses a finite volume method to solve the nonlinear shallow-water equations (GEORGE and LeVeque 2006) and includes optimizations for the inundation of land areas, which involves breaking of waves and a moving wet/dry boundary. It further implements adaptive mesh refinement, allowing varying cell sizes of the computation grid and therefore increased resolution in areas of interest, while keeping calculation time acceptable.

The initial condition of the model is a lake at rest, with a defined bathymetry, including the initial moving mass. The results of the mass-movement simulation are fed into the tsunami model as time series of bathymetry changes. Under the shallowwater assumption, this implies that movements of the lake floor are directly transformed to the overlying water column and the water surface. Any transfer of horizontal momentum from the mass movement to the water column is neglected.

\subsection{Topography Data}

Both models require topographic information of the affected area as basic input. These data are provided as a combined bathymetry/topography data set that was generated from different sources: For the land areas, a high-resolution (2-m cell size) digital elevation model generated mainly from airborne laser 
scanning is available (swisstopo swissALTI3D). This data set describes the topography without vegetation and buildings. Large parts of the lake have been surveyed with high-resolution hydrographic survey systems during two measurement campaigns in 2007 and 2012 (Hilbe et al. 2011; Hilbe and ANSelmetti, in press), providing a high-resolution data set as well (2$\mathrm{m}$ cell size). For the remainder of the lake floor, however, only a coarse raster with limited accuracy interpolated from contour lines (swisstopo DHM25; 25-m cell size) is available.

The simulations of the subaqueous mass movements were generally performed on a grid with a standard cell size of $20 \mathrm{~m}$. Tests with grid sizes of 10 and $50 \mathrm{~m}$ showed only minor differences of runout distance, velocity or geometry of the deposit. Tsunami simulations used cell sizes of 500, 100, 20 and $5 \mathrm{~m}$ on one to four refinement levels, with a standard finest cell size of $20 \mathrm{~m}$ used with adaptive mesh refinement for the whole simulation domain and $5 \mathrm{~m}$ for areas of interest. Reported values are based on simulations with cell sizes of $20 \mathrm{~m}$ (for the entire lake) and $5 \mathrm{~m}$ (for specific areas). A convergence test indicated that higher resolutions do not result in significantly different wave heights (see below).

\subsection{Model Limitations}

The described model has limitations that reduce the accuracy of the obtained results. It will therefore not precisely replicate a mass movement-generated tsunami with well-known boundary conditions, such as in a laboratory experiment. Nevertheless, it is expected to provide estimates of the orders of magnitude of wave heights and inundated areas with their spatial distribution for past events.

Input parameters to the model are not always well constrained. While the considerable uncertainties of the characteristics of the tsunami sources-e.g., volumes, geometries - are evident from the geophysical data (Hilbe and Anselmetti, in press), topography data also introduce additional uncertainty. The data used for the modelling describe the present-day topography without buildings or vegetation. Although it is assumed that this situation is adequate for the simulation of past events that affected a rural area that likely included considerable areas of grassland, the presence of large built-up areas or dense vegetation would significantly influence inundation and limit the inundated area, particularly for short-period waves (KAISER et al. 2011).

"GeoClaw" uses the shallow-water equations, which assume that the flow is hydrostatic and that the vertical momentum can be neglected. This is approximately valid under the condition that the wavelength is much larger than the water depth (George and LeVeque 2006), which is usually the case for earthquake-generated tsunamis on the ocean, and the shallow-water equations have therefore become the standard equations for tsunami models. However, the assumption is rarely fulfilled for the shorter-wavelength tsunamis generated by mass movements and for the interaction processes of the moving mass with the water column during wave generation (LYNETT 2010). Hydrostatic conditions would imply that incremental displacements of the lake floor are directly transferred to the immediately overlying water surface (LeVeque et al. 2011)

Especially for longer travel distances and during wave generation by subaqueous mass movements of limited size, the shallow-water equations suffer from the deficit that they do not model wave dispersion (LøvHolt et al. 2010; Glimsdal et al. 2013). For the case of Lake Lucerne, with wave periods of less than a minute and water depths of $100 \mathrm{~m}$ or more (see below), dispersion is already significant for travel distances of less than $10 \mathrm{~km}$ (GLimsdal et al. 2013; much less for shorter periods), i.e., for wave propagation across the basins, in addition to the effects during wave generation and in the near field. In general, the described shortcomings are expected to lead to an overestimation of the heights of mass movement-generated tsunamis by the shallow water equations (LyNETT 2010).

More advanced models using Boussinesq-type equations partly overcome these limitations and have been broadly applied in studies on mass movementgenerated tsunamis (e.g., WatTs et al. 2003; GEIST et al. 2009). However, these models are often less advantageous and robust for inundation modelling (LøvHOLt et al. 2010), while still neglecting many involved processes. Since the constraints of the tsunamis in Lake Lucerne are subject to substantial 
uncertainties, as well as for reasons of robustness and simplicity, the model presented above is considered an appropriate solution and is thus applied to the described scenarios.

\section{Mass-Movement Scenarios}

Based on the largest documented mass movements of the last 1,000 years, three scenarios of tsunami generation are analysed. In addition, the consequences of a hypothetical failure of an existing sediment volume on an inclined, non-deltaic slope are assessed. The initial mass-movement volumes, which are the main input parameter for the model, are represented by generalized geometries reconstructed from morphological and geophysical data (Fig. 3). They are composed of one or more slabs of uniform thickness, corresponding to the observed mode of the failures on lateral slopes, which typically affect a sediment drape on a discrete failure surface. Runout distances and distributions of deposits used for back analysis are also available from previous studies (Schnellmann et al. 2005; Hilbe et al. 2011; Hilbe and Anselmetti, in press).

\subsection{Weggis slide}

The "Weggis slide" scenario corresponds to the AD 1601 mass movement affecting the sediment drape on the northern lateral slope of the Vitznau basin, described by Schnellmann et al. (2005) and HilBE et al. (2011). The morphologically prominent slide scar is located on a $\sim 6 \mathrm{~km}$ long slope segment with a gliding surface covering an area of more than $2 \mathrm{~km}^{2}$ (Fig. 2). The thickness of the removed sediment drape is rather uniform, with values between 4 and $7 \mathrm{~m}$. The runout of the mass movements on the basin plain is measured here as the distance from the toe of the slope - the sharp decrease in inclination at the base of a lateral slope bordering the basin plainto the most distant front of the deposits. The runout distance of the deposits on the deepest part of the basin plain south of Weggis is $\sim 1.2 \mathrm{~km}$ (SCHNELLMANN et al. 2005). For the initial volume, a sediment package with a constant thickness of $5 \mathrm{~m}$ is assumed (Fig. 3a). Its outline is defined by the prominent headwall escarpment at $20 \mathrm{~m}$ to $80 \mathrm{~m}$ water depth and the toe of the slope, respectively (Hilbe et al. 2011), and encompasses an area of $2.3 \mathrm{~km}^{2}$. Special morphological features, such as parts of the sediment drape that have remained in place, are not considered for model input. The generalized geometry has a volume of $11.5 \times 10^{6} \mathrm{~m}^{3}$.

From back analysis, using the described initial volume, Bingham plastic rheology and a fixed submerged bulk density of $\rho=500 \mathrm{~kg} \mathrm{~m}^{-3}$ for the mass movement (corresponding to the bulk density of the sediment at a depth of $\sim 4 \mathrm{~m}$, reduced by the density of the ambient water; Mazzanti and Bozzano 2009; density value from STRASSER et al. 2011), a yield strength of $\tau_{\mathrm{c}}=5 \mathrm{~Pa}$ and a dynamic viscosity of $\mu=8 \mathrm{~Pa} \mathrm{~s}$ are determined (Table 1). The maximum velocity of the modelled mass movement is in the order of $20 \mathrm{~m} \mathrm{~s}^{-1}$ for typical slope sections and locally reaches $26 \mathrm{~m} \mathrm{~s}^{-1}$ on steep parts; total propagation time is $\sim 5 \mathrm{~min}$. The resulting runout on the basin plain matches the observed distance of $\sim 1.2 \mathrm{~km}$ (Fig. 4a). The geometry of the modelled deposit in the main basin south of Weggis is wedgeshaped with a thick part (up to $3.5 \mathrm{~m}$ ) directly adjacent to the slope and a tapering part towards the basin (Fig. 4a), similar to the documented deposit. While the model is able to reproduce the general outline of the deposits, some observations on Fig. 4a are obviously modelling artefacts: The thin layer covering also the steep parts of almost the complete source area (Figs. 3a, 4a) is most likely an effect of the use of the Bingham plastic rheology, and the lower thickness of the simulated deposit coincident with morphologically prominent lobes close to the toe of the slope ('a' in Fig. 4a) is due to the use of present-day bathymetry data. According to previous studies, these lobes formed only during or after emplacement of the mass-movement deposits as morphological expression of basin-sediment deformation induced by gravitational loading (SChNellmann et al. 2005).

\subsection{Gersau Basin Slide}

The "Gersau basin slide" scenario reproduces the mass movement of AD 1601 in the western part of the Gersau basin, which is characterized by a slide 

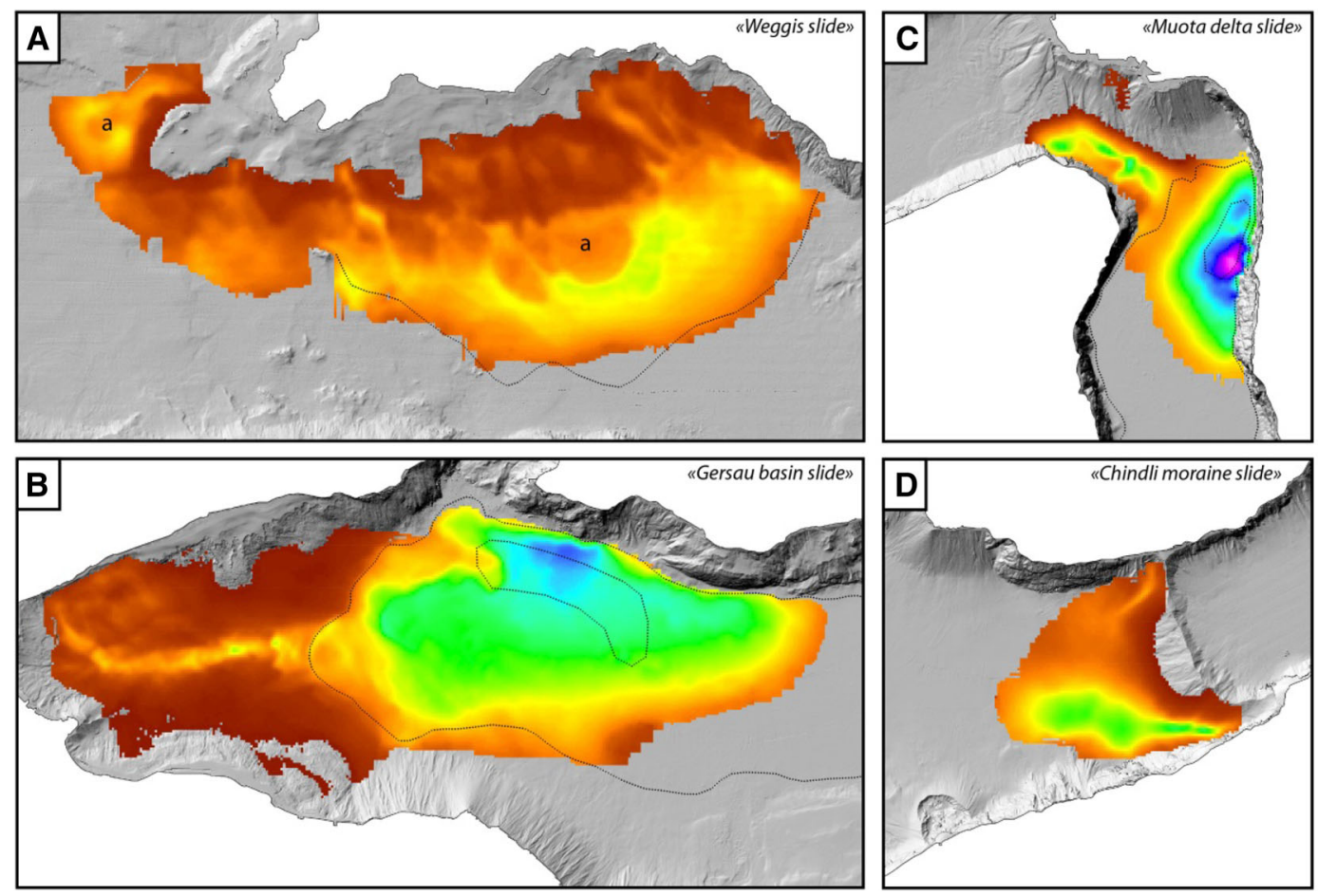

Deposit

thickness

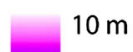

Figure 4

Modelled mass-movement deposits, from initial volumes shown in Fig. 3, using back-analysed parameters and topography data with a cell size of $20 \mathrm{~m}$. Dotted line in a shows extents of deposits after Schnellmann et al. (2005); dotted lines in b and $\mathbf{c}$ show extents (outer boundary) and depocentres (inner boundary) of deposits after HiLBE and ANSELMETTI (in press), which show considerably larger runout on the flat basin plain. Note that a thin layer of material remains on the failure surface in the source area due to the used Bingham rheology

scar covering $3.5 \mathrm{~km}^{2}$ on the slopes and an up to more than 10-m thick deposit with a runout distance of $\sim 5.5 \mathrm{~km}$ on the basin plain (Fig. 2; HILBE and AnselmetTI, in press). This is the most voluminous mass movement documented in the lake. The source area includes non-deltaic lateral slopes to the north and south of the embayment, as well as the front of a small river delta. Stacked escarpments with heights of up to $15 \mathrm{~m}$ indicate that the thickness of the failed sediment package varies considerably within the slide scar. However, the exact geometry of the failed sediments is not known, especially for the part on the delta slope (Hilbe and Anselmetti, in press).

The volume of the mass-flow deposits in the basin is $42 \times 10^{6} \mathrm{~m}^{3}$ (excluding the overlying megaturbidite with additional $10 \times 10^{6} \mathrm{~m}^{3}$ ), of which up to 50 $\%$ of the volume does not originate from the source area, but represents sediments of the deeper parts of the basin that have been entrained or deformed in place (Hilbe and Anselmetti, in press). Based on these constraints, a generalized initial volume with constant thicknesses on the non-deltaic lateral slopes to the north and to the south, as well as a thicker central part (up to $15 \mathrm{~m}$ ) in the area of the delta slope is assumed (Fig. 3b). Total volume of this sediment body is $20.8 \times 10^{6} \mathrm{~m}^{3}$, approximately half the volume of the mass-flow deposit. Due to the higher content of clastic material in the sediments, a higher submerged bulk density of $\rho=600 \mathrm{~kg} \mathrm{~m}^{-3}$ is chosen for the sediments (Table 1).

Based on the back-analysis results, a yield strength of $\tau_{\mathrm{c}}=4 \mathrm{~Pa}$ and a viscosity of $\mu=12 \mathrm{~Pa}$ s are used as simulation parameters. With these values, a maximum velocity of $37 \mathrm{~m} \mathrm{~s}^{-1}$ is calculated locally on the steep $\left(>20^{\circ}\right)$ slopes to the north, while typical maximum values on other slopes are in the range of $25-30 \mathrm{~m} \mathrm{~s}^{-1}$. The main phase of mass-movement propagation down to the basin plain requires $\sim 6 \mathrm{~min}$. Subsequently, slow advancement of the mass movement head $\left(<1 \mathrm{~m} \mathrm{~s}^{-1}\right)$ continues 
beyond 30 min due to the low assumed yield stress. The modelled deposit (Fig. 4b) mimics some general features of the actual deposit, such as the accumulation of material (thickness 4-6 m) below the lateral slope in the north of the basin. However, with a runout of $\sim 4.3 \mathrm{~km}$ on the basin plain, it fails to reproduce the long runout of the actual deposit $(\sim 5.5 \mathrm{~km})$ and its extensive but thin frontal lobe covering the central and eastern parts of the basin plain (Fig. 2).

\subsection{Muota Delta Slide}

The "Muota delta slide" is a single mass movement on the slope of the Muota river delta near the village of Brunnen (Figs. 1, 2), referring to the AD 1687 collapse, which likely affected the central upper part of the delta slope and possibly reached the shoreline, as shown in Fig. 2 (Siegenthaler and Sturm 1991; Hilbe and Anselmetti, in press). The major part of the mass-flow deposits is located at the toe of the delta slope in Lake Uri and has a volume of $11 \times 10^{6} \mathrm{~m}^{3}$ (not including $3 \times 10^{6} \mathrm{~m}^{3}$ for the megaturbidite; Hilbe and Anselmetti, in press). Since the morphology of this active delta slope provides fewer unambiguous constraints on the initial mass movement volume than the other cases, a simple geometry outlined by lateral escarpments to the sides (suggested as lateral boundaries of the failure by Hilbe and Anselmetti, in press) and the 20-m isobath, consisting of two segments reaching water depths of $90 \mathrm{~m}$ (west) and $140 \mathrm{~m}$ (east) with thicknesses of 10 and $16 \mathrm{~m}$, respectively, is assumed (Fig. 3c). Analogous to the Gersau basin slide, the volume of this body amounts to $50 \%$ of the mass-flow deposit, i.e., $5.5 \times 10^{6} \mathrm{~m}^{3}$. For the coarser-grained sediments of this mass movement, a higher submerged density of $\rho=750 \mathrm{~kg} \mathrm{~m}^{-3}$ is used.

Similar to the previous example, the simulated deposit (Fig. 4c) reproduces the position of the depocentre of the actual deposit near the steep eastern lateral slope (Hilbe and Anselmetti, in press), but does not match the geometry with its long runout and symmetric arcuate front (Fig. 2; see below for a discussion). The chosen set of rheology parameters (Table 1), providing acceptable results in back analysis, is $\tau_{\mathrm{c}}=5 \mathrm{~Pa}$ for yield strength and $\mu=12 \mathrm{~Pa} \mathrm{~s}$ for viscosity, resulting in a maximum velocity of $31 \mathrm{~m} \mathrm{~s}^{-1}$, a runout of $1.6 \mathrm{~km}$ on the basin plain $-0.8 \mathrm{~km}$ less than for the actual deposit—and a duration of $\sim 4$ min, after which slow propagation of the front continues.

\subsection{Chindli Moraine Slide}

The western slope of the "Chindli moraine", a $\sim 150 \mathrm{~m}$ high ridge of glacial origin separating the Gersau and Treib basins, is covered by a regularly layered, up to $10-\mathrm{m}$ thick sediment drape resting at $15^{\circ}$ to $25^{\circ}$ inclination (Hilbe et al. 2011). This situation is similar to the non-deltaic lateral slopes of the Gersau and Vitznau basins that have experienced the described extensive failures induced by the $\mathrm{AD}$ 1601 earthquake. However, for reasons thus far unknown, the "Chindli moraine" slope has largely remained stable during this event, with the exception of an isolated, minor mass movement (HiLbE and AnSELMETTI, in press). It currently represents one of the most voluminous slabs of intact sediment drape resting on a medium-inclination slope at Lake Lucerne.

For the "Chindli moraine slide" scenario, a hypothetical mass movement affecting a 7-m thick sediment drape, covering the whole slope $\left(0.4 \mathrm{~km}^{2}\right)$ is assumed, involving a total volume of $2.8 \times 10^{6} \mathrm{~m}^{3}$ (Fig. 3d). The parameters used for the "Gersau basin slide" (yield strength $\tau_{\mathrm{c}}=4 \mathrm{~Pa}$, viscosity $\mu=$ $12 \mathrm{~Pa} \mathrm{~s}$, submerged bulk density $\rho=600 \mathrm{~kg} \mathrm{~m}^{-3}$ ) are also applied to this case (Table 1). The resulting mass movement shows a high maximum velocity of $35 \mathrm{~m} \mathrm{~s}^{-1}$, a runout of $\sim 1.2 \mathrm{~km}$ from the toe of the slope and a propagation time of less than $3 \mathrm{~min}$. The up to 4-m thick simulated deposit (Fig. 4d) extends along the southern lateral slope of the Gersau basin.

\section{Simulated Tsunami Waves}

\subsection{Wave Generation and Propagation}

Tsunami generation and propagation are simulated for the four scenarios based on the mobility analyses described in the previous section. Figure 5 shows maps of the maximum water-surface elevation reached for 

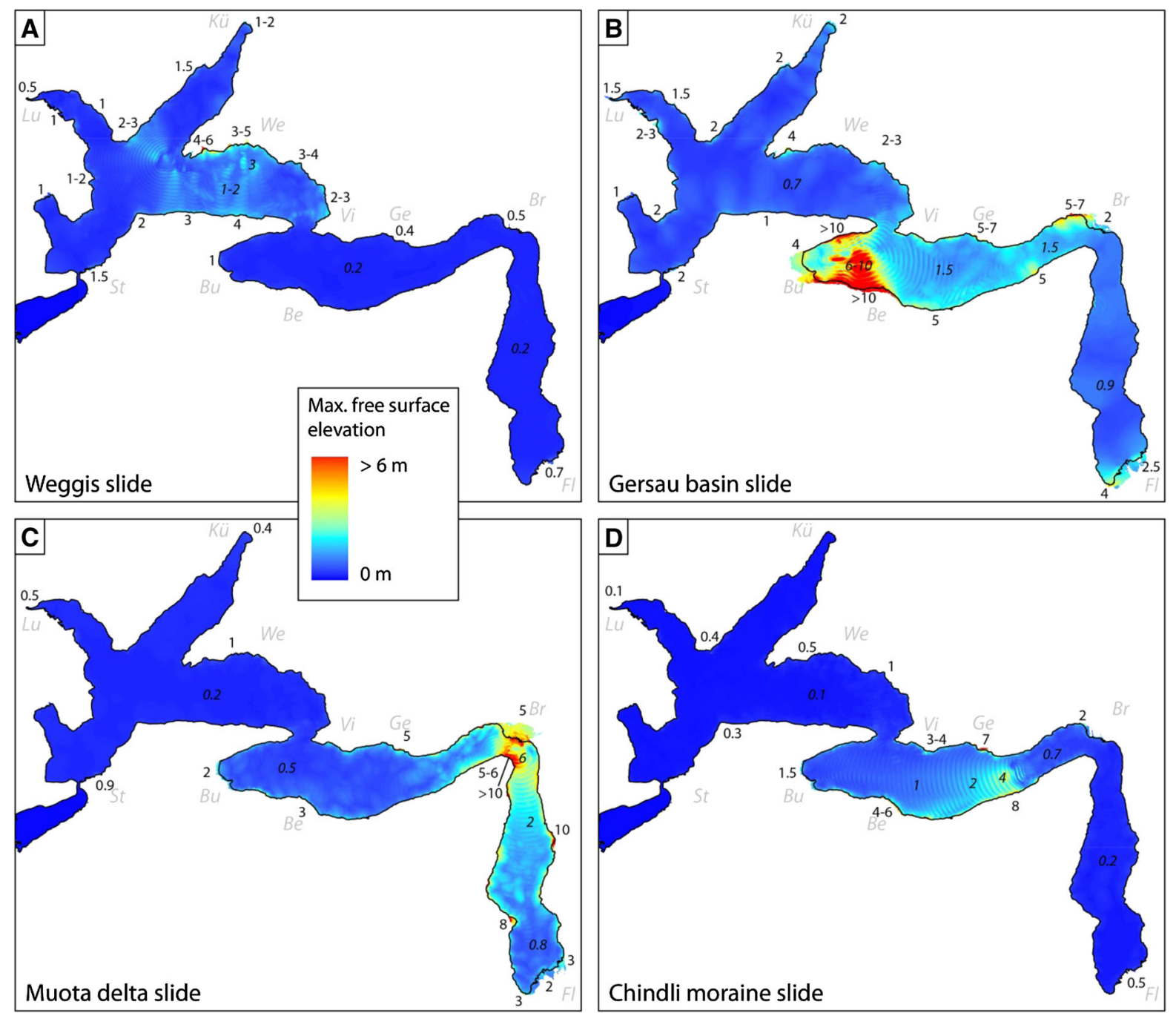

Figure 5

Maximum elevation of free water surface, relative to lake level at rest, for different scenarios. The simulations were performed on a fixed cell size of $20 \mathrm{~m}$ for a period of $90 \mathrm{~min}$ after mass-movement initiation; results were integrated over time steps of $5 \mathrm{~s}$. Italic numbers within the lake mark the maximum wave heights observed on the open lake, numbers on the shore show the approximate maximum free-surface height ( runup) reached during simulation. Reported values and distribution are discussed in the text. The concentric pattern visible close to the tsunami sources is an artefact due to the 5-second integration interval. Light grey letters denote villages on the lakeshore; see Fig. 1 for full names

the four described scenarios during a period of $90 \mathrm{~min}$ after mass-movement initiation. Maximum wave amplitudes of the free water surface relative to lake level at rest on the open lake range from 3 to $10 \mathrm{~m}$ for the scenarios and occur locally at the water surface above the respective slope failures. While the "Weggis slide" (Fig. 5a) only shows a relatively small maximum of $\sim 3 \mathrm{~m}$, the most violent scenario is obviously the "Gersau basin slide" (Fig. 5b), with a maximum height of $\sim 10 \mathrm{~m}$. The "Muota delta slide" (Fig. 5c), with up to $6 \mathrm{~m}$, and the "Chindli moraine slide" (Fig. 5d), with up to $4 \mathrm{~m}$, show intermediate wave amplitudes. The tsunami effects are strongest in the basins that are directly affected by the mass movements and significantly reduced in all other basins. Maximum wave amplitudes on the open lake are generally less than $1 \mathrm{~m}$ in the basins not directly affected, and are often only a few decimetres (Fig. 5). 

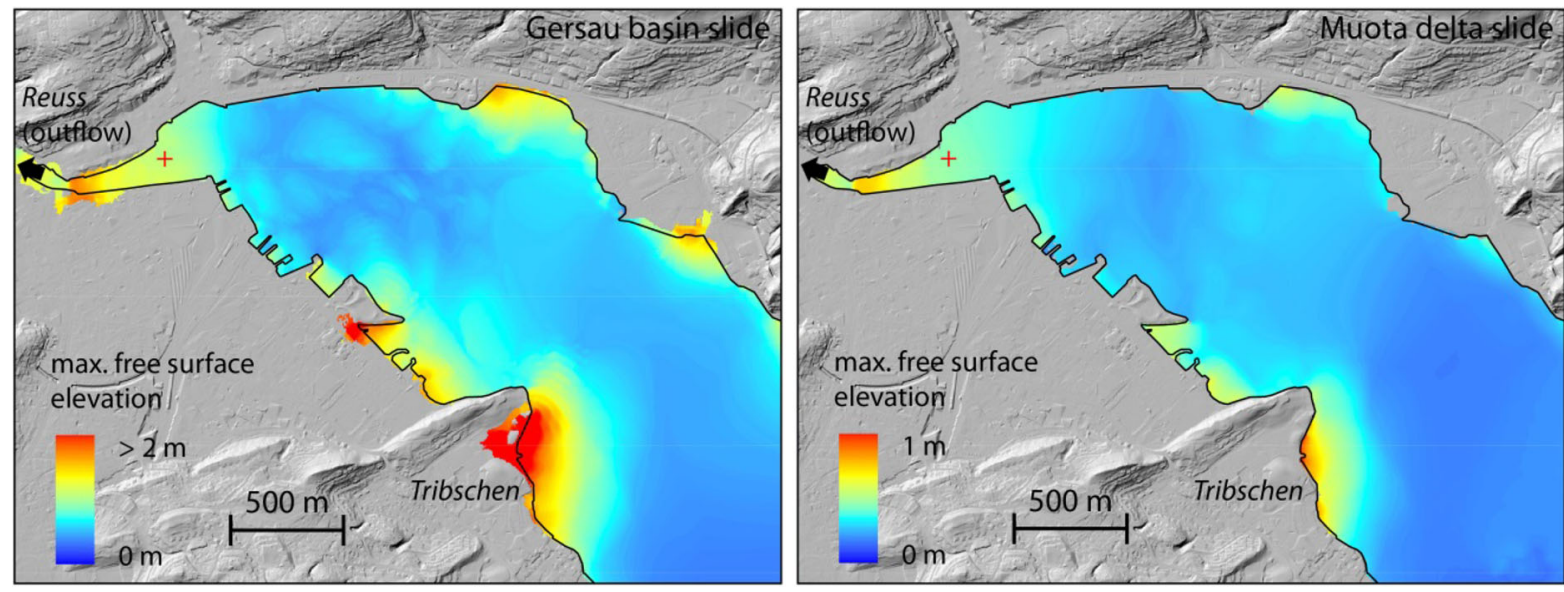

Figure 6

Maximum elevation of free water surface reached in the bay of Lucerne for the "Gersau basin slide" and the "Muota delta slide" scenarios. Inundation of land areas is limited for the former and almost nonexistent for the latter scenario. Note the different colour scales. The red cross marks the location of gauge G1 plotted in Fig. 9

Maximum wave amplitudes and also runup vary considerably due to the local conditions (bathymetry) near the shoreline. Some locations show consistently higher values than neighbouring areas, e.g., the bays indenting the shore near Weggis, or the area of Stansstad (Figs. 1, 5), which is located on a former delta with a submerged platform at shallow depth. Figure 6 illustrates the maximum wave amplitude in the Bay of Lucerne for the "Gersau basin slide" and "Muota delta slide" scenarios. The values in this shallow area (mostly $<10 \mathrm{~m}$ water depth) are generally moderate, and do not produce large runup for either scenario. Peaks occur in a few bays, on the eastern slope of the Tribschen peninsula and in the funnel-shaped region near the Reuss river outflow, while low values prevail, e.g., along the northern shore, where the near-shore water depth is a few metres larger (Fig. 6).

The tsunamis traverse the affected lake basins within the first minutes after mass-movement initiation (Fig. 7): For the "Weggis slide", travel time to the opposite shore of the first positive wave is less than $1 \mathrm{~min}$ after initiation, while around $5 \mathrm{~min}$ are required for the mass movement to reach the final deposition area. The waves with the highest amplitudes on the lake are generated in the initial phase of mass-movement propagation. The end of the lake in Lucerne (see also Fig. 6) is reached by the first wave-which is not necessarily the highest- after $\sim 7 \mathrm{~min}$, and the remote end near Flüelen (Fig. 1) is reached after $\sim 11 \mathrm{~min}$.

Figure 8a shows the simulated time series of freesurface elevation near the outflow of the river Reuss in Lucerne (see Fig. 6 for location) for two scenarios. The water surface oscillates with amplitudes of a few decimetres, and-at least for the "Muota delta slide" - a relatively uniform period close to $10 \mathrm{~min}$, while the simulation for the "Gersau basin slide" contains shorter-period components that lead to an average interval between wave peaks of $\sim 7.5$ min. Similar patterns can be observed at other locations, notably in the southern part of Lake Uri (Fig. 8b; see Fig. 1 for location), where oscillations with periods in the order of $\sim 7 \mathrm{~min}$ are generated. For the "Gersau basin slide", these are superposed by an additional, longer period of $\sim 45$ min.

\subsection{Runup and Inundation}

Close to the shores, maximum wave amplitudes increase, and calculated runup may be several times higher than wave amplitudes on the open lake. Since the onshore areas experiencing runup are often narrow and may only include a few cells, especially on the coarser grids, which use a cell size of $20 \mathrm{~m}$, the significance of reported numbers may be limited. Runup is usually highest along the shores immediately neighbouring the respective subaqueous slope 

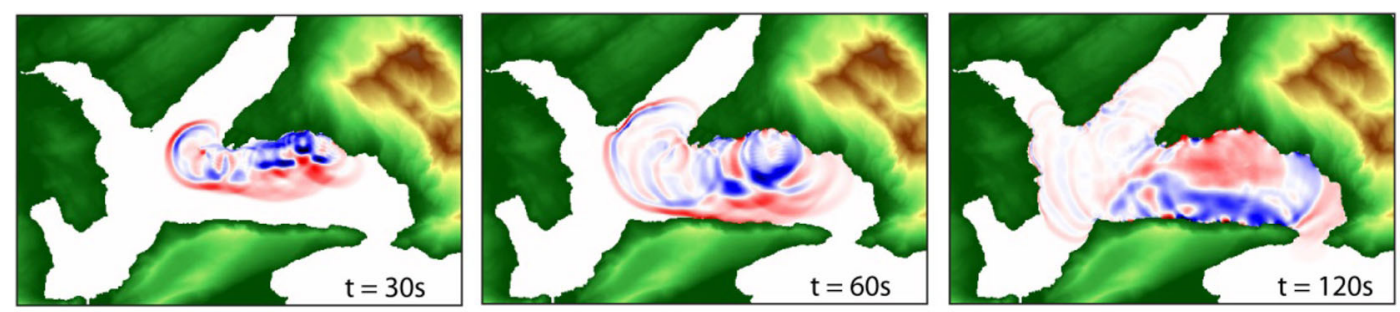

free surface elevation
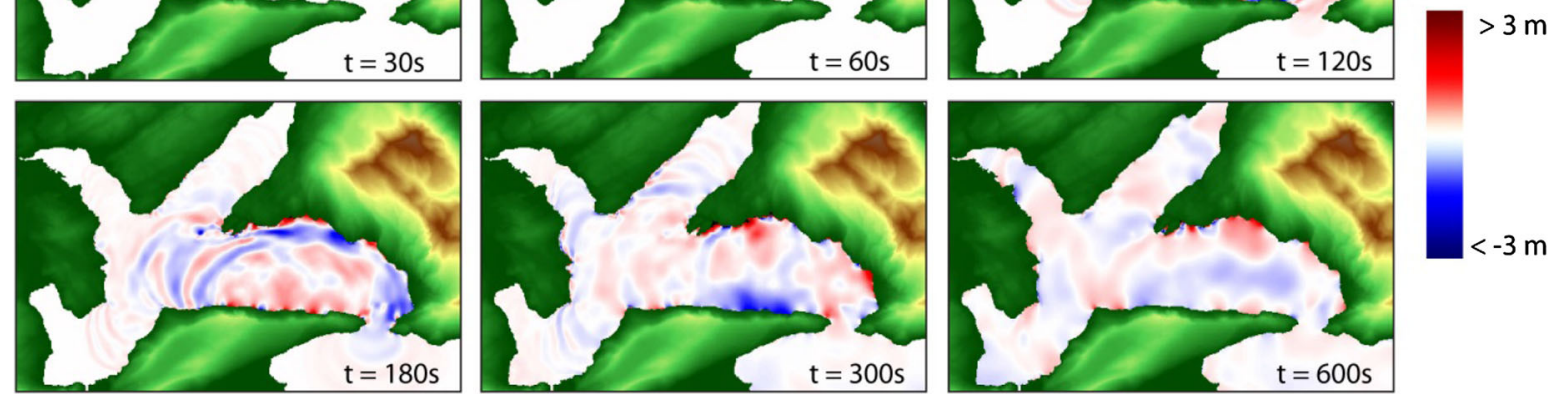

Figure 7

Time steps of wave amplitude for the "Weggis slide" scenario. The first wave travelling to the opposite shore has positive amplitude (red), while the shore "behind" the mass movement is first hit by negative amplitude (blue). Travel time across adjacent basins is only a few minutes. Colors on land areas indicate ground elevation
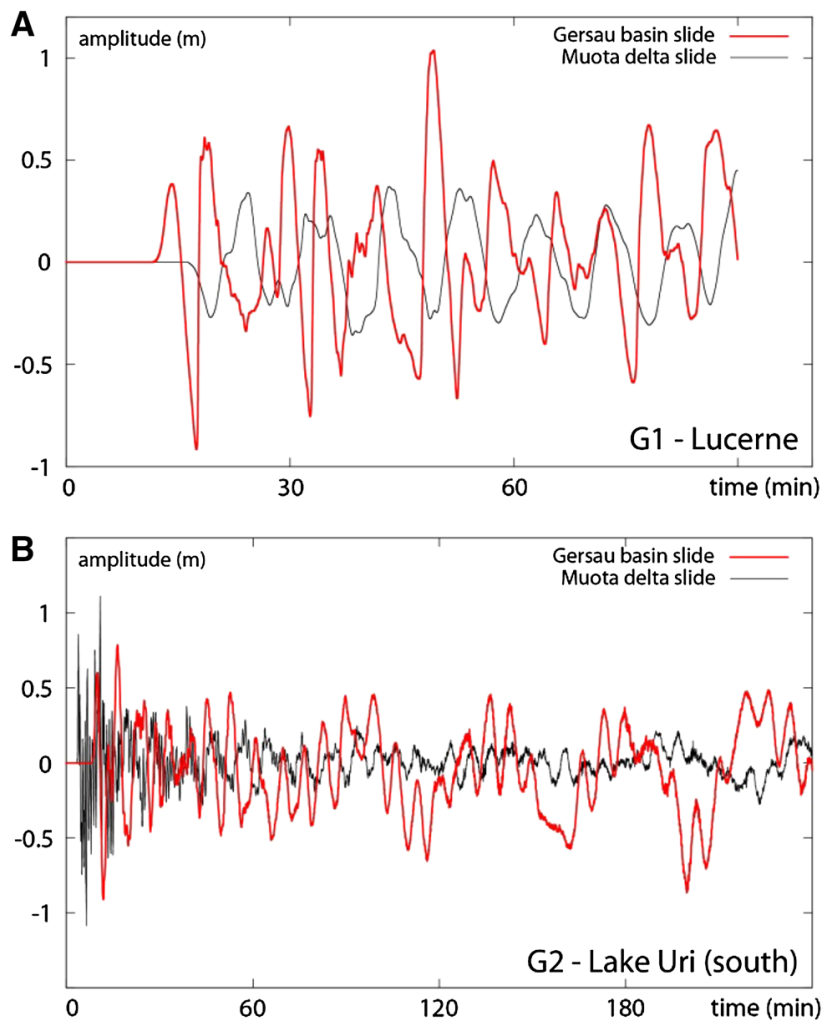

Figure 8

Time series of free surface elevation (water level) at locations in the bay of Lucerne (G1) and in the southern part of Lake Uri (G2); see Fig. 1 for exact positions. Both locations show fairly regular water-level oscillations with periods of a few min. Water depth is $4.6 \mathrm{~m}$ at G1 and $113 \mathrm{~m}$ at $\mathrm{G} 2$ 
failures. On $20-\mathrm{m}$ grids, values of $5 \mathrm{~m}$ or more are calculated for several locations on the lakeshore and for all scenarios. The "Weggis slide" (Fig. 5a) shows the lowest overall runup heights, with 3-6 m near Weggis, 2-4 $\mathrm{m}$ along the steep southern shore of the Vitznau basin and 1-3 $\mathrm{m}$ on the northwestern shore of the Küssnacht basin. In the Gersau, Treib and Uri basins, maximum runup is $1 \mathrm{~m}$ or less for this scenario. For the "Gersau basin slide" (Fig. 5b), which shows the highest values for many parts of the lake, 5-7 $\mathrm{m}$ of maximum runup are reached for exposed locations around the Gersau and Treib basins. Extreme values of $>10 \mathrm{~m}$ are simulated locally next to the mass-movement source areas. Lower maximum runup of $1-2 \mathrm{~m}$ is typically obtained for the other basins, except for susceptible locations near Weggis and at the southern end of Lake Uri (Fig. 5b) with up to $4 \mathrm{~m}$ runup. Near the distal ends of the lake in Lucerne and Küssnacht, this scenario causes more intense effects than the "Weggis slide", even though the source of the latter is closer to these sites (Fig. 5a, b).

The main effects of the "Muota delta slide" (Fig. 5c) are focused on Lake Uri and the Treib basin. Near the mass-movement source, a runup of $>10 \mathrm{~m}$ is calculated on the steep shore facing the delta front, and $\sim 5 \mathrm{~m}$ are obtained on the delta plain using a 20-m grid. Along the western and eastern shores of Lake Uri, high runup occurs locally on several small delta cones, which show lower slope angles compared to the otherwise very steep shores of this basin. At the southern end of Lake Uri, peak runup is 2-3 $\mathrm{m}$. The southern slope of the Treib basin, also located close to the mass-movement source, experiences 5-6 m runup.

Tsunami runup causes inundation on flat areas next to the directly affected basins in all scenarios (see also Fig. 5). Especially the "Gersau basin slide" and the "Muota delta slide" lead to considerable flooding on the alluvial plains near Buochs and Brunnen, respectively. Nowadays, large parts of these areas are densely covered with buildings, which the used terrain model and hence the simulations do not account for. An assessment of the present susceptibility to flooding in these areas would require incorporating the effects of built-up areas, either by using high-resolution terrain models including buildings, or, e.g., by using variable surface roughness (KAISER et al. 2011). Figure 9 shows the maximum onshore flow depth reached for several regions and scenarios, using refined grids with 5-m cell size. In the "Weggis slide" scenario, the waterline extends more than $100 \mathrm{~m}$ inland in three bays on the northern shore of the Vitznau basin near Weggis, while along most parts of shore only a few tens of metres are affected. Maximum flow depth on inundated areas is mostly less than $2 \mathrm{~m}$ (Fig. 9a).

For the "Gersau basin slide", the plain adjacent to the western end of the basin near Buochs is strongly affected (Fig. 9b). The waterline reaches 300-700 m inland during maximum flooding, peak flow depths close to the shore are in the order of $\sim 3 \mathrm{~m}$ and typically $0.5-2 \mathrm{~m}$ further inland. The shore segment south of the present river mouth shows higher values of up to $6 \mathrm{~m}$. The waves of the "Muota delta slide" heavily affect the plain near Brunnen, where an area of almost $1 \mathrm{~km}^{2}$ is flooded (Fig. 9c). The waterline reaches up to $700 \mathrm{~m}$ inland, modelled peak flow depths are up to $5 \mathrm{~m}$ along the lakeshore.

Simulated inundations are less drastic further away from the mass movements, but especially the latter scenarios also cause flooding at the opposite ends of the basins. For the "Gersau basin slide", this affects mostly the western part of the Muota delta alluvial plain (Fig. 9d), while for the "Muota delta slide", the shoreline of the Reuss river delta and the village of Flüelen at its eastern end are concerned, where peak flow depths are mostly below $1 \mathrm{~m}$ (Fig. 9e). On steep lateral shores of the basins, sideentry deltas such as the ones of Gersau (Fig. 9f) and Isleten (Fig. 9g) are the only major areas experiencing significant inundation.

\subsection{Sensitivity to Parameter Variation, Convergence}

The sensitivity of calculated wave heights towards several model input parameters has been tested for the "Muota delta slide", by varying rheology parameters of the mass movement (yield strength, dynamic viscosity), cell size and adaptive mesh refinement used during tsunami simulation, as well as the size and shape of the initial mass-movement volume. The parameters used for the calculations above represent a "reference run" (see also Table 1). Time series of 
max. flow depth (m)

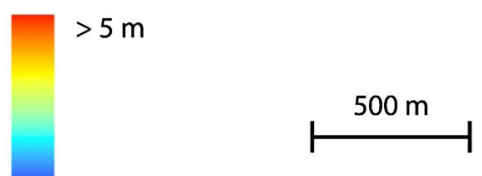

$0 \mathrm{~m}$

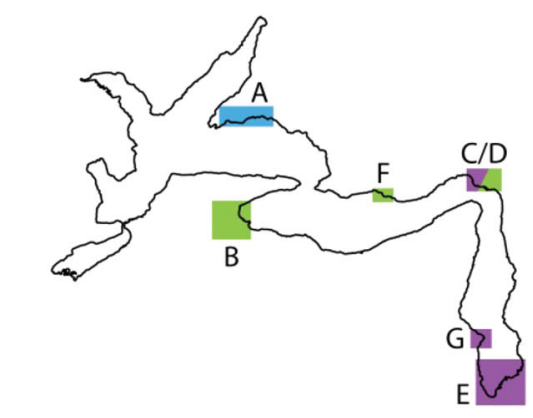

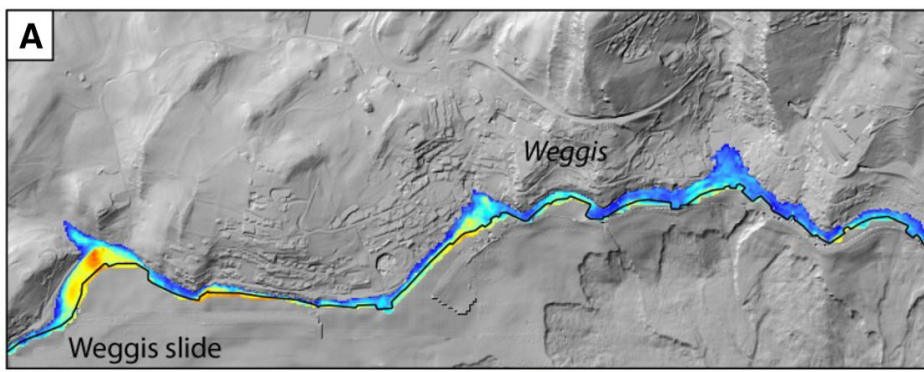
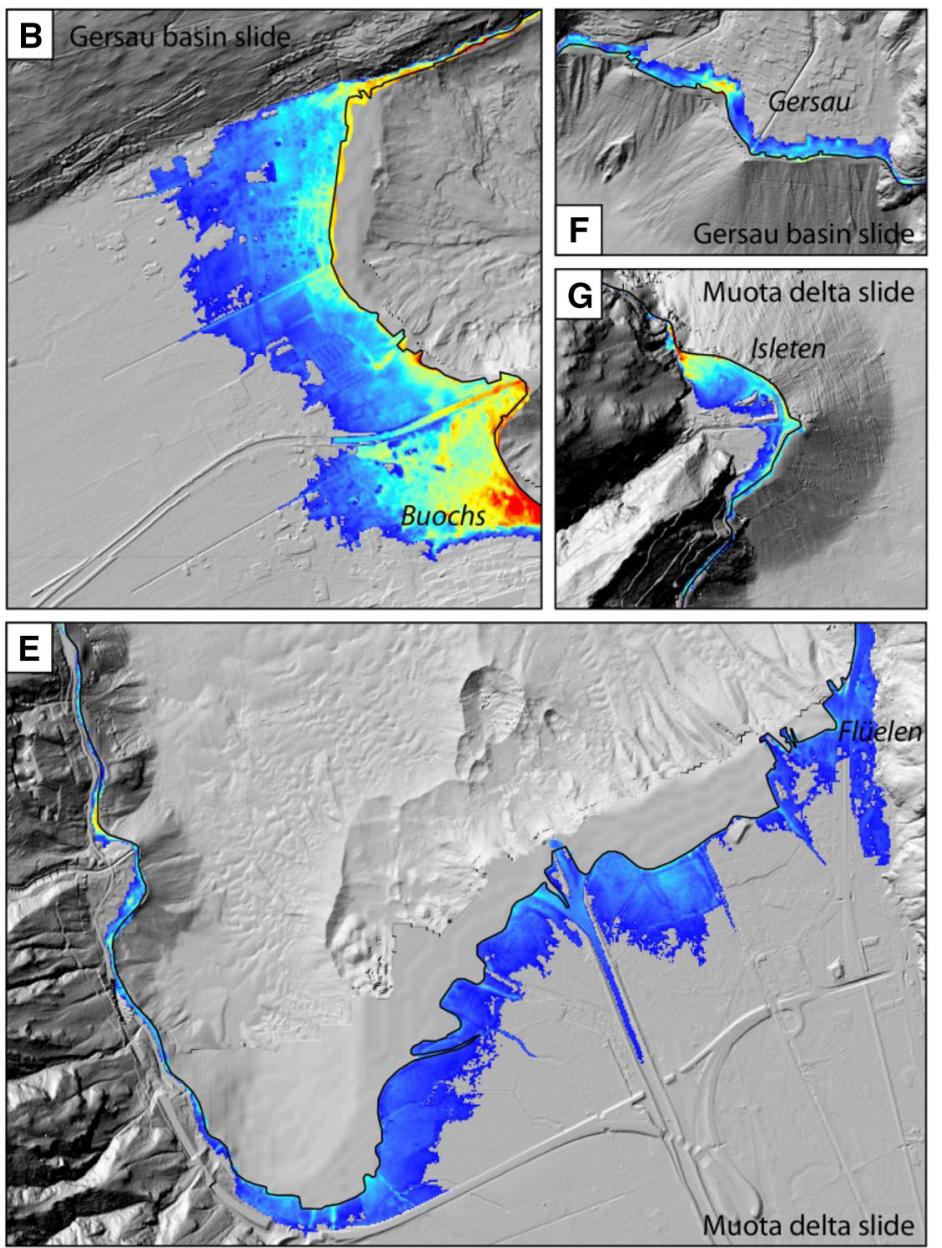

Figure 9

Maps of maximum flow depth simulated for selected onshore areas, for three scenarios: "Weggis slide" blue rectangle (a); "Gersau basin slide" green rectangles $(\mathbf{b}, \mathbf{d}, \mathbf{f})$; "Muota delta slide" violet rectangles $(\mathbf{c}, \mathbf{e}, \mathbf{g})$. Values are only shown for areas that are initially above the water table. Calculations were performed with adaptive mesh refinement on four levels; cell size used for the shown areas is $5 \mathrm{~m}$. Results were integrated over time steps of $2.5 \mathrm{~s}$

free surface elevation or flow depth are shown in Fig. 10 for two locations, one in deep water in the central part of Lake Uri (G3), and one onshore on the plain next to the source area near Brunnen (G4; see Fig. 1 for exact positions). Four of the varied input parameters actually control the behaviour of the mass movement. Simulations using parameters that differ markedly from the back-analysed values may show kinematics of the moving mass that are unrealistic or that show little accordance with the observations, as stated above. Generally, lower viscosity leads to higher velocity and slightly increased runout, while 
Table 1

Parameter sets used for simulations of mass-movement scenarios, results of back analysis

\begin{tabular}{|c|c|c|c|c|}
\hline & $\begin{array}{l}\text { Weggis } \\
\text { slide }\end{array}$ & $\begin{array}{l}\text { Gersau } \\
\text { basin slide }\end{array}$ & $\begin{array}{l}\text { Muota } \\
\text { delta } \\
\text { slide }\end{array}$ & $\begin{array}{l}\text { Chindli } \\
\text { moraine } \\
\text { slide }\end{array}$ \\
\hline Volume $\left(10^{6} \mathrm{~m}^{3}\right)$ & 11.4 & 20.8 & 5.5 & 2.8 \\
\hline Area $\left(10^{6} \mathrm{~m}^{2}\right)$ & 2.3 & 3.3 & 0.4 & 0.4 \\
\hline $\begin{array}{l}\text { Bulk density } \rho \\
\quad\left(\mathrm{kg} \mathrm{m}^{-3}\right)\end{array}$ & 500 & 600 & 750 & 600 \\
\hline $\begin{array}{l}\text { Rheology } \\
\text { (constitutive } \\
\text { model) }\end{array}$ & Bingham & Bingham & Bingham & Bingham \\
\hline $\begin{array}{l}\text { Yield strength } \tau_{\mathrm{c}} \\
\quad(\mathrm{Pa})\end{array}$ & 5 & 4 & 5 & 4 \\
\hline $\begin{array}{l}\text { Dynamic } \\
\text { viscosity } \mu \\
\quad \text { (Pa s) }\end{array}$ & 8 & 12 & 50 & 12 \\
\hline $\begin{array}{l}\text { Propagation time } \\
\text { used (s) }\end{array}$ & 300 & 360 & 240 & 180 \\
\hline
\end{tabular}

higher viscosity significantly reduces runout and velocity. Higher yield strength slightly reduces runout, while lower values do not increase runout in a given time interval, but merely prolong slow propagation of the mass movement on the basin plain. Velocity and runout correlate positively with size and with compactness of the initial mass-movement volume.

Figure 10a illustrates that the mass movementrelated parameters are not the only variables influencing the tsunami simulations, but that wave heights also depend on parameters such as the grid size chosen for calculation. While three runs (fixed 20-m grid; adaptive mesh refinement using cell sizes 500 , 100 and $20 \mathrm{~m}$ with fixed $5-\mathrm{m}$ grid of specific area near the source; fixed 20-m grid with same 5-m grid) show similar amplitudes, one run, which uses only adaptive mesh refinement with cell sizes of 500-20 m, shows higher amplitudes and an earlier onset of flooding for location G4 (see Fig. 1 for position). This discrepancy is probably due to the initial use of the coarsest cell size, which is not able to capture details during the first moments of the mass movement. A convergence test using fixed grid sizes ranging from 400 to $10 \mathrm{~m}$ (Fig. 11a) shows that wave amplitudes during deep-water propagation do not significantly change for a grid size below $20 \mathrm{~m}$, which can thus be considered adequate for wave propagation modelling on the entire lake. For runup, a test with a fixed cell size of $20 \mathrm{~m}$ on the coarse grid and cell sizes of 20 to $2.5 \mathrm{~m}$ on a refined grid (Fig. 11b) was performed. The result depends somewhat on the gauge location, and peak flow depths may be higher or lower on the fine grids compared to coarser grids, but in general, curves for 5 and $2.5 \mathrm{~m}$ on the refined grid show good agreement. A cell size of $5 \mathrm{~m}$ is therefore seen as suitable for higherresolution runup modelling in areas of interest.

Among the parameters related to mass movements, yield strength has only a negligible effect on the calculated wave heights (Fig. 10b). More relevant is dynamic viscosity, for which lower values lead to higher waves (Fig. 10c). Peak wave amplitude on the open lake varies over a range of $\sim 30 \%$ of the reference run value for most tested viscosities. Only for a value of $300 \mathrm{~Pa} \mathrm{~s}$ is the peak amplitude reduced to $\sim 50 \%$ compared to the reference run. Consequently, flow depth is significantly limited for the latter run, while the variation of peak amplitude is small for the other runs. The mass-movement volume has the largest influence on the height of the generated waves (Fig. 10d). On the open lake, doubling of the volume produces a wave that is more than twice the height of the peak reached in the reference run, while half the volume produces only slightly more than one-third of the reference-run wave height. The factors are even more extreme for the flow depth reached during inundation. The shape of the initial volume, which has been modified using different thicknesses of the two compartments (Fig. 3c), and for one run extending the area in deeper water while keeping the volume constant, also significantly influences the wave height (Fig. 10e). Compact bodies at shallower depths generate higher waves than thinner bodies with larger extent, located in deeper water.

\section{Discussion}

\subsection{Mass-Movement Simulations}

The mobility analyses of the three documented mass movements, using the described simple approach of a single-phase Bingham plastic 

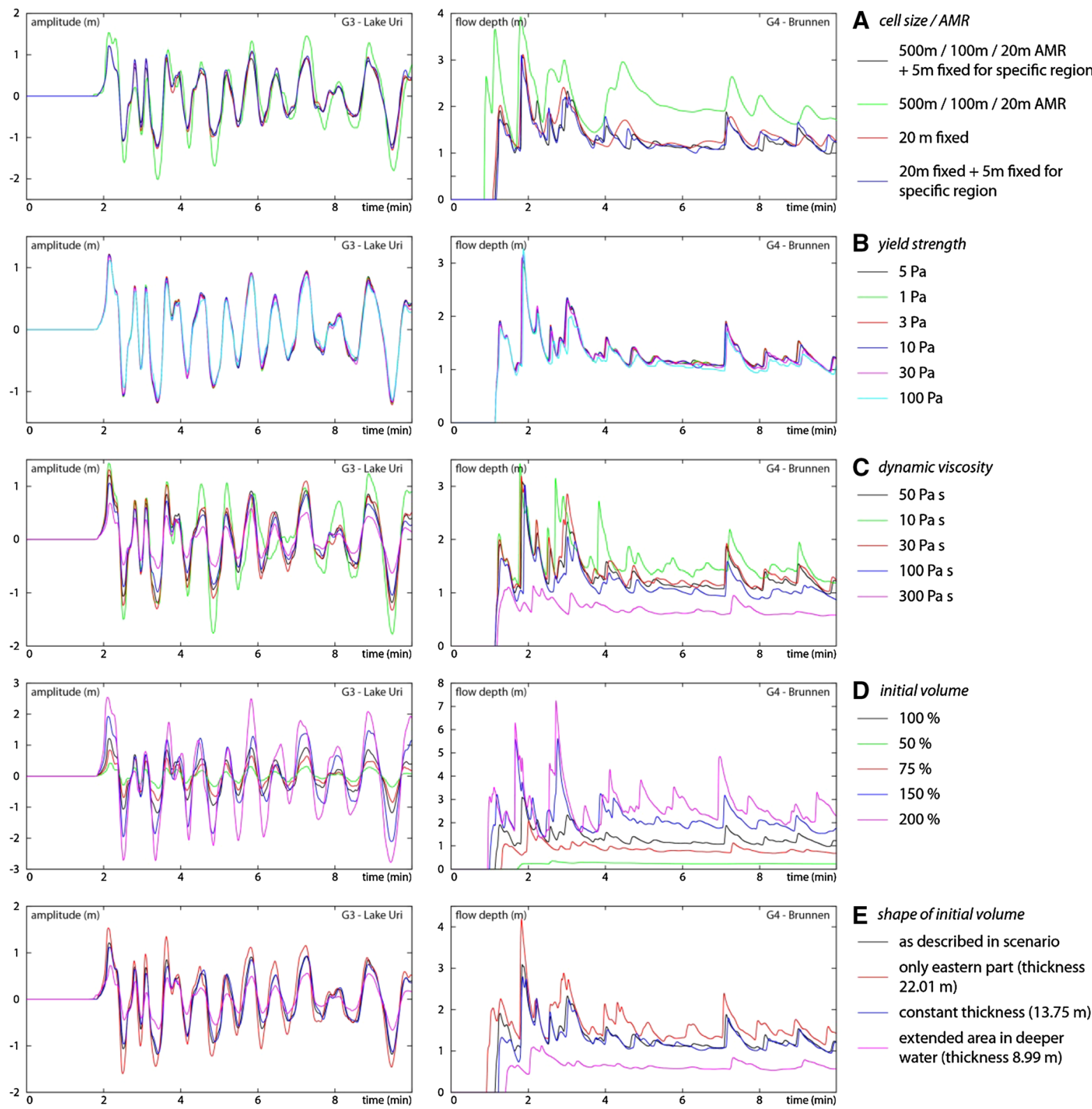

\section{E shape of initial volume \\ - as described in scenario only eastern part (thickness $22.01 \mathrm{~m})$ \\ _ constant thickness ( $13.75 \mathrm{~m})$ extended area in deeper water (thickness $8.99 \mathrm{~m}$ )}

Figure 10

Sensitivity test for "Muota delta scenario" . Left column shows free surface elevation in the central part of Lake Uri (G3 in Fig. 1), right column shows flow depth on an inundated location near Brunnen, close to the mass-movement source (G4 in Fig. 1). Different parameters are varied in the five rows. The curve plotted in black is taken as reference scenario and uses the reconstructed initial volume and the backanalysed parameters for the "Muota delta slide" scenario. Water depth at location G3 is $196 \mathrm{~m}$; ground elevation at location G4 is $1.4 \mathrm{~m}$ above lake level at rest

propagating in two dimensions on arbitrary topography defined by the bathymetry data set, show variable agreement of simulated deposits with the actual ones. For the "Weggis slide", the simulation matches the general features of the deposit reasonably well, while for the "Gersau basin slide" and the "Muota delta slide" the simulated deposits show considerably lower runout than the actual deposits (Fig. 4). Yet, the positions of the depocentres are reproduced well. A major difference between these mass movements is 

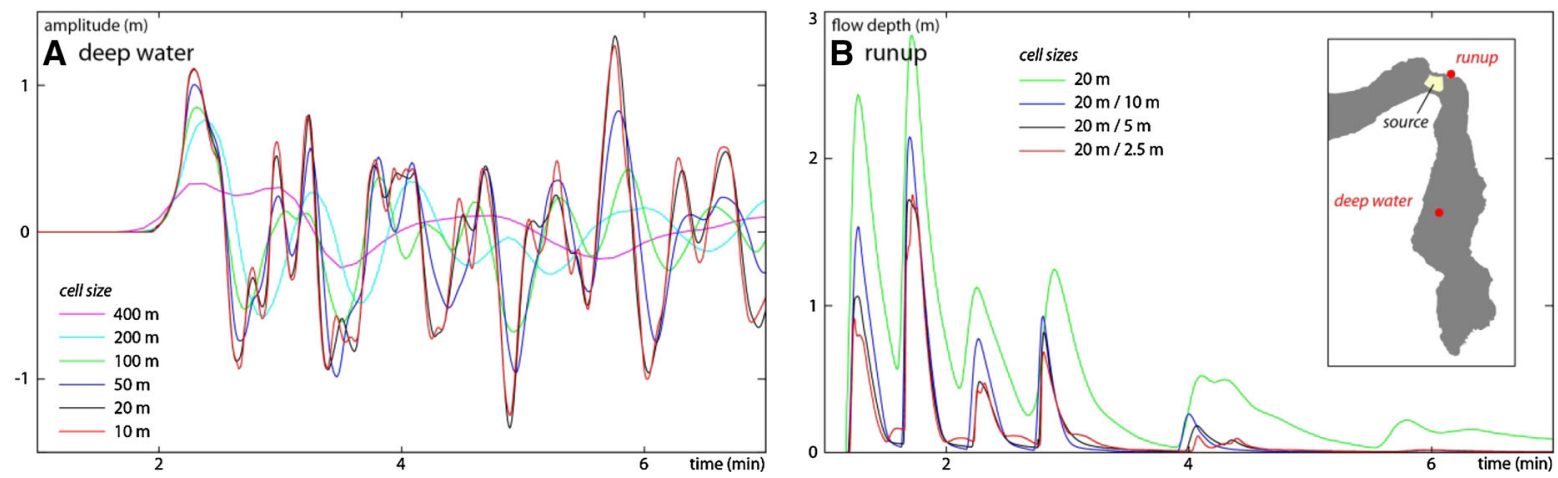

Figure 11

Convergence test for "Muota delta scenario". Left panel (a): Time series of free surface elevation at a deep-water gauge (location shown in inset) as function of (fixed, uniform) cell size of calculation grid. Right panel (b): Time series of flow depth at subaerial gauge (see inset for location) for runup/inundation modelling as function of cell size of refined grid (with $20 \mathrm{~m}$ cell size on coarse grid). The curves in black show the cell sizes taken for the actual models

the complexity of the topography: while the "Weggis slide" occurs on a relatively simple and gently inclined slope leading to a short travel distance along a straight path, the two others occur on steeper slopes and most likely involve curvilinear travel paths or complex situations with different slide segments on slopes facing each other (Fig. 2; HiLbe and ANSELMETTI, in press).

For the latter cases, adjustment of rheology parameters, i.e., decreasing viscosity values, increases runout of the mass movements slightly, but leads to spurious effects during propagation, e.g., bouncing of the moving mass off steep lateral slopes, and does not result in better agreement with the actual deposits. Although uncertainties regarding the initial volumes and the use of present-day topography, which includes the actual deposits and in which these form zones with lower inclination at the base of the slopes, may contribute to limiting runout, it is likely that the simple model does not capture all critical processes governing mass-movement propagation. An often-cited phenomenon that increases runout of mass movements is the reduction of basal friction by incorporation of a thin layer of ambient water between the moving mass and the substrate, also termed hydroplaning (MoHrig et al. 1998; IMRAN et al. 2001). Although Hilbe and Anselmetti (in press) argue that hydroplaning in the strict sense did not occur due to the large amount of pre-existing basin sediment incorporated in the deposit, a similar effect may be obtained by remobilizing the water-rich uppermost sediment layers on the basin plain, which experience virtually undrained loading through the overriding mass movement, leading to the formation of a low-strength layer at the base of the moving mass (Hutchinson and Bhandari, 1971). In any case, the simulations and sensitivity analyses documented above suggest that modelling the exact runout distance on the basin plain at a late stage may be of limited importance for the mass movement as a tsunami source, as the waves are primarily generated during the initial phase. However, for back-analyses using the geometry and specifically the runout of mass movements for the calculation of rheology parameters, this potential shortcoming of a simple single-phase model has to be considered.

Many other studies avoid complexities by using a one-dimensional mass-movement propagation model on a single profile across the slope and replacing the mass movement by a rigid body or by a flexible blanket with constant thickness, assigned with the simulated velocity curve for tsunami simulations (e.g., Marr et al. 2002; Locat et al. 2009, L'HeuReux et al. 2011). Such a procedure would, however, likely cause additional uncertainty in view of a complex topography of Lake Lucerne. Reported rheology parameters from these studies vary strongly, as do the scales of the involved mass movements. Yield strength values applied for the often much bigger mass movements are typically $1-3$ orders of magnitude higher than the numbers found above (Table 1), while dynamic viscosity values in the literature- 
although generally higher as well-are in the same order of magnitude. Interestingly, other studies found that yield strength is the key parameter limiting runout distance of a Bingham plastic material on an inclined slope (ImRAn et al. 2001; MARR et al. 2002), while the results presented above identify viscosity as the main control on the runout distance on a nearly flat basin plain.

\subsection{Modelled and Reported Tsunami Effects}

For the three actual mass movements, not only is geophysical evidence from the lake floor available, but also historical documents describing effects on the lake surface (Siegenthaler et al. 1987; Siegenthaler and Sturm 1991; Schnellmann et al. 2002; Schwarz-Zanetti et al. 2003; Hilbe and Anselmetti, in press). The "Muota delta slide" can be readily linked to a single event in AD 1687. However, the assessment of the "Weggis slide" and "Gersau basin slide" is complicated by the fact that, in reality, they are superposed, as they were parts of one single event, the AD 1601 earthquake.

The observations for the AD 1687 event primarily concern the region around the mass-movement source area (Hilbe and ANSELmetti, in press): The village of Brunnen, which then had only a small fraction of today's extents, was flooded by two main inundation pulses, during which flow depth in the village probably reached 1-2 $\mathrm{m}$, judging from reports of window shutters ripped off houses and large pieces of rock carried through the streets. Runup on the opposite shore near Treib likely exceeded $5 \mathrm{~m}$ locally, as suggested by the reported stripping of vegetation and soil off the bare rock up to heights of more than $5 \mathrm{~m}$ and by the report of a person hit by the wave in the first floor of a tavern located on the lakeshore (Hilbe and Anselmetti, in press). The calculations for the "Muota delta slide" scenario show even higher numbers, with typically 5-6 m and locally $>10 \mathrm{~m}$ runup on the opposite shore (Fig. 5c) and peak flow depth of 2-4 $\mathrm{m}$ in the area of the former village (Fig. 9c), suggesting that wave heights and inundations close to the tsunami source may be overestimated by the simulation. Further away from the source, however, the simulation reproduces the reports of the village of Flüelen being flooded and the observed lake-level oscillations with amplitudes in the order of $\sim 60 \mathrm{~cm}$ in Lucerne more adequately (Figs. 6a, 8a, 9e).

Descriptions of the AD 1601 event mention runup of up to $4 \mathrm{~m}$ on the northwestern shore of the Küssnacht basin, but no serious damage from water waves in the city of Lucerne, where the most striking observation was a peculiar lake-level oscillation with a period of $10 \mathrm{~min}$ and an amplitude of 1-2 $\mathrm{m}$, which caused the outflowing river Reuss to periodically change flow direction (SIEGENTHALER et al. 1987; Schnellmann et al. 2002). The individual simulations for the "Weggis slide" and "Gersau basin slide" scenario predict somewhat lower maximum runup of 3 and $2 \mathrm{~m}$ in the Küssnacht basin, respectively, and peak amplitudes of roughly 0.5 and $1.5 \mathrm{~m}$ in Lucerne (Figs. 5a, b, 6). A lake-level oscillation at the outflow in Lucerne is modelled for the "Gersau basin slide", however, it includes shorter-period components that lead to an irregular period of less than $10 \mathrm{~min}$. For the "Muota delta slide", however, a regular period of $10 \mathrm{~min}$ is obtained (see above, Fig. 8). Considering the effects and additional uncertainty from the superposition of the two scenarios, the simulations replicate the phenomena satisfactorily.

The sparser reports of this event from the area around the Gersau basin describe water waves "like mountains" rising in the middle of the lake, suggesting a wave height of at least several metres, up to $\sim 750 \mathrm{~m}$ of inundated land near Buochs, and houses with sleeping people carried onto the lake in Beckenried, leading to the death of at least eight people (Schnellmann et al. 2002; Hilbe and AnselMETTI, in press). These dramatic effects are at least matched by the simulation of the Gersau scenario, which shows up to $10 \mathrm{~m}$ of wave height on the open lake, up to $\sim 700 \mathrm{~m}$ inundation distance on the plain near Buochs and very high runup of $>10 \mathrm{~m}$ in Beckenried. As for the AD 1687 event, an overestimation of wave heights by the simulation can be suspected close to the source areas, as extreme runup exceeding $10 \mathrm{~m}$ in a populated area would probably have led to more pronouncedly reported consequences.

Similar to the Lucerne bay, a periodic oscillation or seiche is reported from Lake Uri (SIEGENTHALER et al. 1987). The simulated period of $7 \mathrm{~min}$ for 
the "Gersau basin slide" (Fig. 8b) in Lake Uri appears slightly shorter than the fundamental period for a seiche. The latter can be approximated by the fundamental period of a seiche in a rectangular, closed basin of length $L$ and depth $h$, given by $2 L /$ $(g h)^{1 / 2}$ (RABINOvich 2010; $g$ is the gravitational acceleration of $\sim 9.8 \mathrm{~m} / \mathrm{s}^{2}$ ), and amounts to $\sim 8 \mathrm{~min}$ for a 10.5-km long and 200-m deep basin. The longer period of $\sim 45$ min (Fig. 8b) can possibly be attributed to a cyclic exchange of water between different basins. However, while the mass movements and resulting tsunamis evidently produce seiches that are best visible at the outer ends of the lake, the simulated wave pattern in the directly affected basins and in the central parts of the lake is more complex and obviously does not follow a simple seiche movement (cf. Fig. 8b). It appears that the evolution of mass movement-induced tsunamis into a pattern of standing wave oscillations or seiches is a common process in certain isolated or semi-enclosed basins (e.g., Harbitz et al. 1993)

\subsection{Tsunami Hazard on Lake Lucerne}

As predicted by the simulations and supported by historical reports, all scenarios are capable of producing wave runup exceeding $5 \mathrm{~m}$, and possibly reaching $>10 \mathrm{~m}$ locally for extreme cases. These values are comparable to those of well-studied examples in the marine environment, where reported runup heights of investigated historical mass movement-generated tsunamis typically reach up to $\sim 10 \mathrm{~m}$ and up to $\sim 20 \mathrm{~m}$ for extreme cases (HARBITZ et al. 2014). However, the scales of the mass movements, with volumes of up to a few tens of millions of cubic metres, and therefore also the areas affected by the tsunamis, are much smaller in Lake Lucerne. Major effects are typically restricted to the shorelines within a few kilometres distance from the subaqueous mass movements. Wave propagation times to these shores typically range from seconds to a few minutes, and leave very little time for possible measures. Considering the vulnerability of the potentially affected areas, this hazard may be worth consideration. Unlike in AD 1601 and 1687, today large parts of the alluvial plains and the immediate lakeshore host buildings and infrastructure that would likely experience heavy damage in case of an event similar to the simulated scenarios.

Only the largest mass movements-comparable in size to the presented scenarios-are expected to produce waves that bear the potential for widespread damage around affected basins, while events with significantly smaller volumes likely generate only small waves and local runup. The large volume necessary for basin-wide, damaging tsunamis limits the number of potential source areas, as these require extensive areas covered with potentially unstable, unconsolidated sediments of at least several metres thickness, resting on a slope with an inclination within a certain range $\left(\sim 10^{\circ}-20^{\circ}\right)$, gentle enough to allow long-term sediment accumulation, but also steep enough for the sediments to become unstable under certain conditions (SCHNELlmann et al. 2006; STRASSER et al. 2011).

River-delta slopes and non-deltaic lateral slopes covered by a drape of glaciolacustrine and lacustrine sediments are the two main types of source area distinguished by Hilbe and Anselmetti (in press). River deltas are obvious candidates regarding the availability of sediments, and even for medium-sized lateral fan deltas, mass-movement volumes in the order of $10^{6} \mathrm{~m}^{3}$ would not appear extraordinary in case of massive failures. However, large-scale mass movements on these slopes seem to be rare. The $\mathrm{AD}$ 1687 event, the basis for the "Muota delta slide" scenario (see above), is the only documented case of this type in Lake Lucerne, and the mechanism responsible for this aseismic failure is not understood thus far (Hilbe and Anselmetti, in press). The tsunami hazard associated with delta failures, which would primarily concern the "proximal" Treib, Uri and Gersau basins (Fig. 1), therefore cannot be properly assessed at the current stage.

The other source-area type, non-deltaic lateral slopes, is considered geotechnically stable under static conditions and requires additional load for failure, most commonly earthquake shaking (STRASSER et al. 2007). However, susceptibility to failure (and obviously also the eventually mobilized volume) depends strongly on the amount of potentially unstable sediment present on the slope. In the mapped part of the lake (HiLbe et al. 2011; Hilbe and AnselmetTi, in press), potential source areas of this 
type coincide largely with the source areas of the previous mass movements of the AD 1601 and 2220 BP events (Fig. 2) and have therefore lost most of their sediment cover. Strasser et al. (2011) have shown for the Chrüztrichter and Vitznau basins that in their present state, these slopes, as well as most other slopes around these basins, are fairly stable even under external load.

This suggests that even strong seismic shaking may not lead to large-scale slope collapses, but more likely to failures of smaller sediment volumes, thus limiting the size of expected tsunami waves. An individual sediment package on the lateral slope off Weggis ('a' in Fig. 2), which was not affected by the AD 1601 mass movement and is identified by STRASSER et al. (2011) as potentially unstable in case of an earthquake similar to AD 1601, includes a volume of $\sim 10^{6} \mathrm{~m}^{3}$. Estimating from the simulation of the "Weggis slide", which involves $\sim 10^{7} \mathrm{~m}^{3}$, failure of this package may produce runup in the order of $\sim 2 \mathrm{~m}$ on the immediately neighbouring shore, but the generated waves on the lake are expected to be only small, with heights of less than $1 \mathrm{~m}$. However, depending on the sedimentation rates and the geotechnical conditions on the slopes, the potential of large-scale failures is expected to increase slowly over time with growing sediment cover (STRASSER et al. 2011).

As an exception to this, the western slope of the Chindli moraine, described in section 4.4, meets the mentioned criteria for source areas, and is presently covered by a largely intact sediment drape. A hypothetical failure of this slope, which would presumably require strong seismic shaking, as it has remained stable during two nearby earthquakes with $M_{\mathrm{W}} \sim 5.9$ and $M_{\mathrm{W}} \sim 5.7$ in AD 1601 and 1774, respectively (FÄH et al. 2011; Hilbe AND Anselmetti, in press), leads to a simulated maximum runup of $>5$ metres on the neighbouring fan deltas of Gersau and Beckenried (Figs. 5d, 9f), a relatively high value for the moderate volume that may be attributed to the steep slope angle and thus a high simulated massmovement velocity. Even if the scenario overestimates the near-field wave and runup heights, its effects would be damaging for the affected, densely inhabited areas.

\section{Conclusion}

The numerical experiments performed in this study are generally able to simulate effects of past mass movement-induced tsunamis in Lake Lucerne to a satisfactory degree. With some exceptions, especially in the near field, the used simple numerical model, which is based on two-dimensional depthaveraged equations, generally succeeds in predicting the orders of magnitude of past events reported by historical accounts. The hazard assessment is based on four scenarios, three of which attempt to reproduce the largest subaqueous mass movements documented for the last millennium. Since these mass movements affect substantial parts of the potential source areas for major failures, the scenarios are assumed to illustrate the most drastic events expected in the lake, although volumes of the mass movements, which depend, e.g., on sedimentation rates and recurrence rates of events, and therefore the magnitude of the generated tsunamis could even be higher.

The first stage of the model simulates the propagation of the respective mass movements, starting from a generalized sediment package reconstructed from bathymetry data. While the modelled deposits match the actual deposits well for a failure on a planar slope with a straight propagation path, they do not reproduce the long runout of the mass movements on steeper slopes with more complex propagation paths. One reason for this may be some process reducing basal drag for the mass movement on the basin plain, which is, however, not likely to have significant impact on tsunami generation.

Based on the results of the first stage, the generation, propagation and inundation of a tsunami are simulated in a second stage, which uses the nonlinear shallow-water equations. Although these are known to be problematic for mass movement-generated tsunamis and tend to overestimate wave heights, the magnitudes of the effects at a certain distance from the mass movements are acceptably reproduced. However, in the near field close to the source areas of the mass movements, it is suspected that simulated wave heights and runup considerably overestimate the actual values.

Still, maximum runup values of more than $5 \mathrm{~m}$ convey that large subaqueous mass movements may 
be a considerable threat for installations and the population along the shores. Areas identified as susceptible for comparably higher runup are, e.g., indented parts of the shoreline and also fan deltas, which have relatively lower slope angles for submerged and subaerial slopes. The flat alluvial plains in the main valleys are expected to experience largescale inundation. However, the results also suggest that the morphology of Lake Lucerne with separated basins tends to limit the most serious consequences to the directly affected basins. This is illustrated by the effects in the city of Lucerne, which, despite a relatively flat topography, does not experience significant inundation in any of the scenarios, as it is protected by an extensive shallow-water area.

Next to the analysis of potential triggers, most importantly earthquakes, the proposed steps for a systematic evaluation of the hazard constituted by subaqueous mass movements and related tsunamis include (1) extensive mapping using geophysical tools in order to identify potential source areas, (2) geotechnical analyses at selected locations in order to assess failure susceptibility, and (3) tsunami modelling and validation. More advanced numerical tsunami models providing meaningful results, especially for the near field, would be advantageous for this purpose.

\section{Acknowledgments}

Geodata by swisstopo was used with permission JA100119. The developers of the used open-source computer codes are gratefully acknowledged for sharing their code with the scientific community. Two anonymous reviewers are thanked for their constructive comments.

\section{REFERENCES}

Assier-Rzadkiewicz, S., Heinrich, P., Sabatier, P.C., Savoye, B., and Bourillet, J.F. (2000), Numerical modelling of a landslidegenerated tsunami: The 1979 Nice event. Pure and Applied Geophysics, 157, 1707-1727.

BAFU (2009), Hydrologisches Jahrbuch der Schweiz 2008, Umwelt-Wissen Nr.0921, Swiss Federal Office for the Environment, Berne, 578 pp.
BFS (2013), Statistisches Jahrbuch der Schweiz 2013, 120. Jahrgang, Verlag Neue Zürcher Zeitung, Zürich, 592 pp.

Bardet, J.-P., Synolakis, C.E., Davies, H.L., Imamura, F., and OкаL, E.A. (2003), Landslide tsunamis: Recent findings and research directions, Pure and Applied Geophysics, 160, 1793-1809.

Beguería, S., Van Asch, T.W.J., Malet, J.-P., and Gröndahl, S. (2009), A GIS-based numerical model for simulating the kinematics of mud and debris flows over complex terrain, Natural Hazards and Earth System Sciences, 9, 1897-1909.

Berger, M.J., George, D.L., LeVeque, R.J., and Mandli, K.T. (2011), The GeoClaw software for depth-averaged flows with adaptive refinement, Advances in Water Resources, 34, 1195-1206.

Bondevik, S., Løvholt, F., Harbitz, C., Mangerud, J., Dawson, A., and Svendsen, J.I. (2005), The Storegga Slide tsunami - comparing field observations with numerical simulations, Marine and Petroleum Geology, 22, 195-208.

Fäh, D., Giardini, D., Kästli, P., Deichmann, N., Gisler, M., Schwarz-Zanetti, G., Alvarez-Rubio, S., Sellami, S., Edwards, B., Allmann, B., Bethmann, F., Wössner, J., Gassner-Stamm, G., Fritsche, S., and Eberhard, D. (2011), ECOS-09 Earthquake Catalogue of Switzerland, Release 2011, Report SED/ECOS/R/ 001/20110417, Swiss Seismological Service, ETH, Zürich, $42 \mathrm{pp}$.

FincKh, P., Kelts, K., and Lambert, A. (1984), Seismic stratigraphy and bedrock forms in perialpine lakes, Geological Society of America Bulletin, 95, 1118-1128.

Fritz, H.M., HAgER, W.H., and Minor, H.-E. (2004), Near field characteristics of landslide generated impulse waves, Journal of Waterway, Port, Coastal, and Ocean Engineering, 130, 287-302.

Fuji, Y., Satake, K., Shin'ichi, S., Sinohara, M., and Kanazawa, T. (2011), Tsunami source of the 2011 of the Pacific coast of Tohoku earthquake, Earth Planets Space, 63, 815-820.

Geist, E.L., LynetT, P.J., and Chaytor, J.D. (2009), Hydrodynamic modeling of tsunamis from the Currituck landslide, Marine Geology, 264, 41-52.

George, D.L., and LeVeque, R.J. (2006), Finite volume methods and adaptive refinement for global tsunami propagation and local inundation, Science of Tsunami Hazards, 24, 319-328.

Girardclos, S., Schmidt, O.T., Sturm, M., Ariztegui, D., Pugin, A., and Anselmetti, F.S. (2007), The 1996 AD delta collapse and large turbidite in Lake Brienz, Marine Geology, 241, 137-154.

Glimsdal, S., Pedersen, G.K., Harbitz, C.B. and Løvholt, F. (2013), Dispersion of tsunamis: does it really matter? Natural Hazards and Earth System Sciences, 13, 1507-1526.

Grilli, S.T., TAYlor, O.S., BAXTer, C.D.P., and Maretzki, S. (2009), A probabilistic approach for determining submarine landslide tsunami hazard along the upper east coast of the United States, Marine Geology, 264, 74-97.

Harbitz, C.B., Pedersen, G., and GJevik, B. (1993), Numerical simulations of large water waves due to landslides, Journal of Hydraulic Engineering, 119, 1325-1342.

Harbitz, C.B, Løvholt, F., and Bungum, H. (2014), Submarine landslide tsunamis: how extreme and how likely, Natural Hazards, 72, 1341-1374.

Hilbe, M., Anselmetti, F.S., Eilertsen, R.S., Hansen, L., and WILDI, W. (2011), Subaqueous morphology of Lake Lucerne (Central Switzerland): implications for mass movements and glacial history, Swiss Journal of Geosciences, 104, 425-433. 
Hilbe, M., and Anselmetti, F.S. (in press), Signatures of slope failures and river-delta collapses in a perialpine lake (Lake Lucerne, Switzerland), Sedimentology, doi:10.1111/sed.12120.

Huber, A. (1982), Felsbewegungen und Uferabbrüche an Schweizer Seen, ihre Ursachen und Auswirkungen, Eclogae geologicae Helvetiae, 75, 563-578.

HUTCHINSON, J.N., and BHANDARI, R.K. (1971), Undrained loading, a fundamental mechanism of mudflows and other mass movements, Géotechnique, 21, 353-358.

Imran, J., Parker, G., Locat, J., and Lee, H. (2001), 1 D numerical model of muddy subaqueous and subaerial debris flows, Journal of Hydraulic Engineering, 127, 959-968.

JiANG, L., and LeBLOND, P.H. (1992), The coupling of a submarine slide and the surface waves which it generates, Journal of Geophysical Research, 97, C8, 12731-12744.

Kaiser, G., Scheele, L., Kortenhaus, A., Løvholt, F., Römer, H., and LESCHKA, S. (2011), The influence of land cover roughness on the results of high resolution tsunami inundation modeling, Natural Hazards and Earth System Sciences, 11, 2521-2540.

Kremer, K., Simpson, G., and Girardclos, S. (2012), Giant Lake Geneva tsunami in AD 563, Nature Geoscience, 5, 756-757.

Kulikov, E.A., Rabinovich, A.B., Thomson, R.E., and Bornhold, B.D. (1996), The landslide tsunami of November 3, 1994, Skagway Harbor, Alaska, Journal of Geophysical Research, 101, C3, 6609-6615.

LeVeque, R.J., George, D.L., and Berger, M.J. (2011), Tsunami modelling with adaptively refined finite volume methods. Acta Numerica, 20, 211-289.

L'Heureux, J.-S., Glimsdal, S., Longva, O., Hansen, L., and HARBITZ, C.B. (2011), The 1888 shoreline landslide and tsunami in Trondheimsfjorden, central Norway, Marine Geophysical Research, 32, 313-329.

Locat, J., Lee, H., ten Brink, U.S., Twichell, D., Geist, E., and SAnsoucy, M. (2009), Geomorphology, stability and mobility of the Currituck slide, Marine Geology, 264, 28-40.

Løvholt, F., Pedersen, G., and Glimsdal, S. (2010), Coupling of Dispersive Tsunami Propagation and Shallow Water Coastal Response, The Open Oceanography Journal, 4, 71-82.

LYNETT, P. (2010), Hydrodynamic modeling of tsunamis generated by submarine landslides: Generation, propagation and shoreline impact, In: Mosher, D.C. et al. (eds.), Submarine mass movements and their consequences, Advances in Natural and Technological Hazards Research, 28, 685-694.

Marr, J.G., Elverhøi, A., Harbitz, C., Imran J., and HarfF, P. (2002), Numerical simulation of mud-rich subaqueous debris flows on the glacially active margins of the Svalbard-Barents Sea, Marine Geology, 188, 351-364.

Mazzanti, P., and Bozzano, F. (2009), An equivalent fluid/equivalent medium approach for the numerical simulation of coastal landslides propagation: theory and case studies, Natural Hazards and Earth System Sciences, 9, 1941-1952.

Mohrig, D., Whipple, K.X., Hondzo, M., Ellis, C., and Parker, G. (1998), Hydroplaning of subaqueous debris flows, Geological Society of America Bulletin, 110, 387-394.

Moore, J.G., Schweickert, R.A., Robinson, J.E., Lahren, M.M., and KitTs, C.A. (2006), Tsunami-generated boulder ridges in Lake Tahoe, California-Nevada, Geology, 34, 965-968.

Rabinovich, A.B., Thomson, R.E., Kulikov, E.A., Bornhold, B.D., and Fine, I.V. (1999), The landslide-generated tsunami of November 3, 1994 in Skagway Harbor, Alaska: A case study, Geophysical Research Letters, 26, 3009-3012.
Rabinovich, A.B. (2010) Seiches and harbor oscillations, In: Kim, Y.C. (ed.), Handbook of coastal and ocean engineering. World Scientific Publishing, Singapore, pp. 193-236.

SATAKE, K. (2012) Tsunamis generated by submarine landslides, In: Yamada, Y. et al. (eds.), Submarine mass movements and their consequences, 5th International Symposium, Advances in Natural and Technological Hazards Research, 31, 475-484.

Schnellmann, M., Anselmetti, F.S., Giardini, D., McKenzie, J.A., and WARD, S.N. (2002), Prehistoric earthquake history revealed by lacustrine slump deposits, Geology, 30, 1131-1134.

Schnellmann, M., Anselmetti, F.S., Giardini, D., and McKenzie, J.A. (2005), Mass movement-induced fold-and-thrust belt structures in unconsolidated sediments in Lake Lucerne (Switzerland), Sedimentology, 52, 271-289.

Schnellmann, M., Anselmetti, F.S., Giardini, D., and McKenzie, J.A. (2006), 15,000 Years of mass-movement history in Lake Lucerne: Implications for seismic and tsunami hazards, Eclogae geologicae Helvetiae, 99, 409-428.

Schwarz-Zanetti, G., Deichmann, N., Fäh, D., Giardini, D. Jimenez, M.-J., Masciadri, V., Schibler, R., and Schnellmann, M. (2003), The earthquake in Unterwalden on September 18, 1601: A historico-critical macroseismic evaluation, Eclogae geologicae Helvetiae, 96, 441-450.

Siegenthaler, C., Finger, W., Kelts, K., and Wang, S. (1987), Earthquake and seiche deposits in Lake Lucerne, Switzerland, Eclogae geologicae Helvetiae, 80, 241-260.

Siegenthaler, C., and Sturm, M. (1991), Slump induced surges and sediment transport in Lake Uri, Switzerland, Verhandlungen der Internationalen Vereinigung für theoretische und angewandte Limnologie, 24, 955-958.

Stegmann, S., Strasser, M., Anselmetti, F., and Kopf, A. (2007), Geotechnical in situ characterization of subaquatic slopes: The role of pore pressure transients versus frictional strength in landslide initiation, Geophysical Research Letters, 34, L07607.

Strasser, M., Anselmetti, F.S., Fäh, D., Giardini, D., and Schnellmann, M. (2006), Magnitudes and source areas of large prehistoric northern Alpine earthquakes revealed by slope failures in lakes, Geology, 34, 1005-1008.

Strasser, M., Stegmann, S., Bussmann, F., Anselmetti, F.S., Rick, B., and Kopf, A. (2007), Quantifying subaqueous slope stability during seismic shaking: Lake Lucerne as model for ocean margins, Marine Geology, 240, 77-97.

Strasser, M., Hilbe, M., and Anselmetti, F.S. (2011), Mapping basin-wide subaquatic slope failure susceptibility as a tool to assess regional seismic and tsunami hazards, Marine Geophysical Research, 32, 331-347.

Strasser, M., Monecke, K., Schnellmann, M., and Anselmetti, F.S. (2013), Lake sediments as natural seismographs: A compiled record of Late Quaternary earthquakes in Central Switzerland and its implication for Alpine deformation, Sedimentology, 60, 319-341.

Synolakis, C.E., Bardet, J.-P., Borrero, J.C., Davies, H.L., OKal, E.A., Silver, E.A., SweEt, S., and TAPPIN, D.R. (2002), The slump origin of the 1998 Papua New Guinea Tsunami, Proceedings of the Royal Society A, 458, 763-789.

ten Brink, U.S., Lee, H.J., Geist, E.L., and Twichell, D. (2009), Assessment of tsunami hazard to the U.S. East Coast using relationships between submarine landslides and earthquakes, Marine Geology, 264, 65-73. 
Titov, V., Rabinovich, A.B., Mofjeld, H.O., Thomson, R.E., and GonZÁLEZ, F.I. (2005), The global reach of the 26 December 2004 Sumatra tsunami, Science, 309, 2045-2048.

WARD, S.N. (2001), Landslide tsunami, Journal of Geophysical Research, 106, 11201-11215.

WARD, S.N., and DAY, S. (2010), The 1958 Lituya Bay landslide and tsunami - a tsunami ball approach, Journal of Earthquake and Tsunami, 4, 285-319.

Watts, P., Grilli, S.T., Kirby, J.T., Fryer, G.J., and Tappin, D.R. (2003), Landslide tsunami case studies using a Boussinesq model and a fully nonlinear tsunami generation model, Natural Hazards and Earth System Sciences, 3, 391-402.

WATTS, P. (2004), Probabilistic predictions of landslide tsunamis off Southern California, Marine Geology, 203, 281-301.

Wesseling, C.G., Karssenberg, D.-J., Burrough, P.A., and Van DEURSEN, W.P.A. (1996), Integrating dynamic environmental models in GIS: The development of a Dynamic Modelling language, Transactions in GIS, 1, 40.

(Received August 20, 2013, revised July 11, 2014, accepted July 14, 2014, Published online August 7, 2014) 